\title{
High-Performance Work Systems and Organizational Performance in Emerging Economies: Evidence from MNEs in Turkey
}

\author{
Mehmet Demirbag • David Collings • Ekrem Tatoglu • Kamel Mellahi • \\ Geoffrey Wood
}

\section{Abstract:}

- This study examines the association between the usage of high-performance work systems (HPWS) by subsidiaries of multinational enterprises (MNEs) in Turkey and employee and subsidiary level outcomes.

- The study is based on a survey of 148 MNE subsidiaries operating in Turkey.

- The results show that the usage of HPWS has a significant positive impact on employee effectiveness. However, their impact on employee skills and development, and organizational financial performance are far less clear.

- Our findings highlight the extent to which HWPS need to be adapted to take account of context-specific institutional realities.

Keywords: High performance work systems (HPWS), Institutional theory, Performance outcomes, Multinational enterprise (MNE), Turkey

\section{Authors}

Prof. Mehmet Demirbag $(\bowtie)$

Strathclyde Business School, University of Strathclyde, Glasgow, G4 0QU, United Kingdom

e-mail: mehmet.demirbag@strath.ac.uk

Prof. David Collings

DCU Business School, Dublin City University, Dublin 9, Ireland

Prof. Ekrem Tatoglu

Faculty of Economics and Administrative Sciences, Bahcesehir University, Besiktas, Istanbul, 34349, Turkey.

Prof. Kamel Mellahi

Warwick Business School, The University of Warwick, Coventry, CV4 7AL, United Kingdom.

Prof. Geoffrey Wood

Warwick Business School, The University of Warwick, Coventry, CV4 7AL, United Kingdom. 


\section{Introduction}

The nature and extent of linkages between human resource management (HRM) practices and performance has become a key concern in international business and management studies over the past two decades (Bowen and Ostroff 2004; Boxall, 2013; Guest 1997; Guest 2011; Guthrie 2001; Marescaux et al. 2013; Monks et al. 2013; Paauwe and Boselie 2003; Wall and Wood 2005; Wright et al. 1999). However, even though there is now a much wider understanding of the linkages in a range of national contexts, significant gaps remain in our understanding of the relationship between HRM practices and performance in the multinational enterprise (MNE). Whilst the MNE represents an important means of dissemination of HRM practices throughout the globe, there remains much debate as to the extent to which HRM practices are universally applicable, and whether HRM practices should be adapted to account for locally embedded norms and conventions in subsidiaries (Farndale and Paauwe 2007; Lawler et al. 2010). This study explores the relationship between the deployment of key elements of high performance work systems (HPWS) and organizational performance in an emerging market setting.

Although there is not a universally agreed definition of HPWS, they generally converge around a focus on investment in people, employee empowerment, good communication systems, performance management, fairness in setting pay, promotion on the lines of merit, job security, and low status differentials (Heffernan et al. 2011; Pfeffer 1998). Some of these - such as intraorganizational informal status differentials - may be relatively difficult to measure and compare between contexts (Metiu 2006). Others may largely represent a product of employment legislation and state enforcement capabilities; this is particularly true for employment security. Whilst participation and involvement will, again, at least in part be a product of legislation, Brewster et al. (2007) encountered a great deal of variation in practice even within relatively highly regulated settings. In this paper, we concentrate on those dimensions of HPWS where the organization is likely to have a fair degree of discretion, and where practices are relatively easy to compare: communication and participation, investment in people, and in approaches to reward and promotion. We did not set out to compare organizations that were formally committed to 
HPWS at a strategic level, but rather to compare the performance consequences of the relative utilization of key dimensions of HPWS in practice.

Terms used broadly and interchangeably to define HPWS include high commitment management (Legge 2005), high involvement management (Lawler 1986), and flexible production systems (MacDuffie 1995). We adopt the term HPWS to emphasize how particular configurations of HRM practices can improve firm profitability. Such practices centre on fostering employee involvement and the human capital of the organization more generally, while reversing Taylorist practices (Wood 1999). HWPS are associated with firms seeking competitive advantage through quality and productivity (Nolan and O'Donnell 1995), and the adoption of high-cost, high-skill employment practices (Marchington and Grugulis 2000).

\section{The Dissemination of Practice: Institutional Enablement and Constraint}

Theoretically, the dissemination of HRM practices is often explained by institutional theory which suggests that firms will adopt practices in line with the context in which they operate, via the process of 'isomorphism': going local yields superior outcomes as it lowers transaction costs and allows firms to fully benefit from the particular competitive advantages a context confers (DiMaggio and Powell 1983; Marsden 1999; Hall and Soskice 2001). This means that firms are likely to vary their practices according to context, rather than adopt universal best practices. This does not, of course, explain which set of institutional arrangements will assume dominance in the case of firms that cross national boundaries; much of the early literature on comparative capitalism devotes little or no attention to this question (e.g. Hall and Soskice 2001; Lincoln and Kalleberg 1990). However, the international business literature's view on institutions and MNEs has, in the past, been similarly constrained, focusing on a limited range of institutional features as providing incentives for actors (Deeg and Jackson 2008, p. 541). More recently, there have been efforts to redress these shortfalls, conceptualizing of institutions as 'thick' or dense sets of 
interlocking social relations that provide the basis for complementarities (Deeg and Jackson 2008, p. 541).

However, although the literature on comparative capitalism makes bold predictions as to how firm level work and HRM practices are likely to differ according to setting, much of the empirical evidence marshalled by such literature concentrates on broad societal and labour market features (see Hall and Soskice 2001; Amable 2003). If institutions are ultimately about stabilizing particular production regimes and exchange relationships, making economic life possible (see Boyer 2012), then the actual activities of frontline employees and how they are managed assume particular importance. Although there is a growing body of work that seeks to redress this imbalance (Goergen et al. 2012), much of this has concentrated on mature market settings. The body of institutional literature is very diverse, but there is broad consensus that particular sets of practices are more viable in some settings than others (Goergen et al. 2012; Lincoln and Kalleberg 1990; Hall and Soskice 2001). There is also a body of literature that suggests that HPWS will work better in contexts where stakeholder rights are more strongly embedded; in other words, the performance outcomes from the deployment of HWPS will be better in coordinated markets than other types of capitalism (Dore 2000; Lincoln and Kalleberg 1990). This means that in contexts where stakeholder rights are weaker (liberal markets) and/or more fluid (emerging and mixed markets), there will be weaker incentives to adopt HPWS. The configurational perspective to HRM similarly recognizes a far greater degree of variability in HRM systems and accounts for differences in adoption and performance to contextual variables (Heffernan et al. 2011; Lepak et al. 2006). Early empirical research posits that of all management functions HRM is likely to be the one most likely to vary according to setting (Kobayashi 1982). Hence, it could be argued that HPWS practices are likely to be tailored to local realities (see also Rosenzweig 2006). However, the existing literature on HPWS in emerging markets is somewhat limited. 


\section{'Best Practice Winning Out?'}

It can alternatively be argued that emerging globally diffusing best practices are generally captured under the term HPWS; more optimistic accounts suggest that as these yield optimal outcomes, they will ultimately 'win out' irrespective of context (see Lawler et al. 2010). Within the 'best practice' approach to HRM, Pfeffer (1998) argues that there is a set of HRM practices which improve performance regardless of context. Delery and Doty (1996) term this approach the universal approach; others use the term best practice (Marchington and Grugulis 2000). Moreover, it can be argued that global standardization can facilitate the creation of efficiency gains, cross-border equity and comparability and/or the operation of the MNE's internal labour market (Almond et al. 2005).

There is some empirical support for the idea that HPWS have become 'taken for granted' and have become embedded in MNEs and in the global economy more generally (Pudelko and Harzing 2007; Lawler et al. 2010). It can be argued that MNEs are relatively insulated from pressures to adapt their management practices to local norms, owing to their global standing, which, in turn, means that they are generally in a position to promote new structures and practices rather than respond to pressures to adopt them (Kostova et al. 2008). Again, empirical evidence provides growing support for the positive relationship between the deployment of highperformance HRM practices and firm performance (Guthrie 2001; Huselid et al. 1997). These factors combined with increases in the flow of ideas globally mean that convergence of HRM practices might be expected (Björkman et al. 2007; Pudelko and Harzing 2007).

\section{The Global and the Local}

Current institutionalist writing suggests that, given that MNEs are subject to weaker national institutional ties than single country firms, they may adopt policies that fit in with locally embedded production regimes, that are in line with the dominant corporate governance paradigm in their country of origin, and/or pioneer emerging practices that will ultimately assume dominance across the global ecosystem (Morgan 2012, p. 19; Deeg and Jackson 2008; Jessop 
2012). In other words, transnationality dilutes institutional ties giving MNEs a greater room for manoeuvre (Morgan 2012). In turn, national settings may become less distinct with the inflow of MNEs, with hybrid types of practice emerging (see Deeg and Jackson 2008, p. 556).

MNEs enter particular markets for a wide range of reasons. Inter alia, these can include a need to access raw materials, lucrative or potentially lucrative consumer markets, obtaining cheaper labour supplies and/or accessing the competitive advantages a particular institutional environment confers (Demirbag et al. 2008; Whitley 2010; Morgan 2012). In the case of the latter, MNEs have strong incentives to fit into established local production regimes: in the instances higher value added production paradigms are predominant, there will be strong incentives to adopt HPWS. However, when lower value added production paradigms predominate; it is likely that the institutional supports (in terms, for example, of skills and job protection) for HPWS will be weaker. In other words, HPWS are less likely to yield superior outcomes in such settings.

Duality approaches suggest that both external (whether country of origin and/or common global best practices) and country of domicile pressures may exert an impact on the relative viability of practices (Kostova and Roth 2002). Areas such as relative tendency to engage investment in people may be particularly prone to country of domicile pressures, given variations in national skills and educational systems, in job protection, and staff turnover rates. In other words, in some contexts, specific types of training interventions may be more needed and/or work better than others.

\section{HPWS and Institutional Considerations}

In this paper, we examine the impact of HPWS on organizational outcomes in MNEs' subsidiaries in a key emerging economy - Turkey. We chose the term organizational outcomes, as we consider financial performance to be too narrow a measure of impact (see Guest 1997). Following on from recent research we made a distinction between financial, organizational and HRM-related outcomes (Dyer and Reeves 1995; Boselie et al. 2005). Specifically, in addition to 
financial performance, we consider the employee as a key stakeholder in the enterprise and hence look at the link between the relative usage of specific types of HRM practice on skills, capabilities, effectiveness, and commitment outcomes.

Much of the earlier literature on comparative capitalism concentrated on mature capitalist archetypes, which it was held, embodied mature complementarities (Dore 2000; Hall and Soskice 2001); other types of capitalism would necessarily drift towards one or other of the mature capitalist archetypes: in other words, towards a liberal market or coordinated market economy (Hall and Soskice 2001; Hancke et al. 2007). HPWS may diffuse into many different settings, but, it can be argued, are more likely to be sustained in contexts where complementarities are most developed, and hence, the performance outcomes are more likely to be superior. More recently, it has been recognized that many other national economies, whilst somewhat more institutionally fluid, are likely to retain distinct characteristics for a sustained period of time, and, indeed, may have some areas of competitive advantage, even if as a whole, they are less prosperous than the mature varieties of capitalism (Lane and Myant 2007). There have been a number of attempts to identify the key institutional features of the Mediterranean world (Amable 2003), Africa (Wood et al. 2010; Wood and Frynas 2006), Latin America (Schneider 2009) and Eastern Europe (Lane and Myant 2007). All these types of economies are in many respects distinct. However, a common feature emerging from this analysis is that less mature capitalist archetypes are characterized by weaker and partial institutional coupling (Wood and Lane 2012), and segmentation between larger firms and the state sector on the one hand and weaker and much less regulated informal and small businesses on the other hand (Wood et al. 2010; Lane and Myant 2007). The former area of activity has, in many national contexts, been subject to much liberalization, with reduced state protectionism and support, privatizations, and the influx of foreign players (Wood et al. 2010; Schneider 2009). Whilst market reforms have led to the decay of many firms and industries in the face of intensifying international competition, other firms have prospered in such climates owing to the adoption of new technologies and forms of work organization, combined with an ability to draw on and reconfigure past institutional legacies and 
associated social ties which may facilitate activities in a range of areas from optimizing supply relations to human capital development (see Crouch and Voelzkow 2004). MNEs may be quite well equipped to adopt such hybrid models, combining greater awareness with international trends and advances with that of the realities of working in different institutional settings (see Morgan 2012).

However, in addition to obvious successes and failures, it can be argued that in many emerging market settings, firms will remain wedded to traditional authoritarian patriarchal approaches to management. The latter mitigate essentially poor terms and conditions of service with informal ties and mutual understandings with workers, allowing for a certain flexibility in areas such as recruitment (in favour of family and friends of existing staff), informal credit, and the granting of ad hoc leave to staff in the case of personal misfortune (Webster and Wood 2005; Wood and Frynas 2006; Psychogios and Wood 2010). In other words, whilst seemingly outdated, such practices may have some benefits in emerging market settings. In the case of MNEs, senior international managers may have little interest or ability in sustaining such close patriarchal relations with staff, although many local managers may remain persistently wedded to this approach (Psychogios and Wood 2010), pulling MNEs in different directions.

Turkey represents a valuable setting for exploring these debates for a number of reasons. The context of HRM in the Turkish context is significantly different than in many western economies, and clearly different to North America where HPWS emerged. Although the business environment has evolved somewhat over the past decade (Aycan et al. 2000; Goregenli 1997; Fikret-Pasa et al. 2001; Bondy and Starky 2014), management in Turkey remains significantly different from that of western European countries (Brown and Humphreys 2002; Küskü and Zarkada-Fraser 2004), resulting in challenges to the implementation of new western HRM practices in the Turkish context (Kaya 2006; Tanova and Nadiri 2005). Many Turkish firms do indeed follow the authoritarian-patriarchal model alluded to above (Aycan et al. 2000). At the firm level, typical Turkish firms are characterized by centralized decision making, reliance on short term planning, highly personalized and strong leadership combined with limited delegation, 
characteristics which seem largely incompatible with many of the principles underscoring HPWS (Glaister et al. 2008; Fikret-Pasa et al. 2001; Ronen 1986). Hence, Turkey represents a very interesting context to explore how western HPWS impact on performance outcome in MNE subsidiaries in contexts where traditional authoritarian-patriarchal approaches remain deeply embedded, and the extent to which such realities may mediate the diffusion of modernizing approaches to people management.

Furthermore, the Turkish context provides an interesting research setting characterized by slow institutional change. This is a result of the bold attempts to become both a more Western style market economy and member of the European Union (EU), processes which have arguably involved both marketization and infusion of some social features of the EU model (Agartan 2010). Additionally, Turkey was the first Muslim country to bid for EU membership. Turkey is also a rapidly developing country and the largest national economy in Central and Eastern Europe, the Balkans and the Middle East. The Turkish economy has shown remarkable performance over the last ten years and is the fastest growing economy in Europe, and, indeed, one of the fastest growing economies in the world. The GDP levels more than tripled from US\$ 231 billion in 2002 to US\$ 794 billion in 2012 (IMF 2013). Volumes of trade are also growing robustly- reaching US\$ 389 billion in 2012 (Republic of Turkey - Ministry of Economy 2013a). A sound macroeconomic strategy in combination with prudent fiscal policies and major structural reforms in effect since 2002 has facilitated Turkey's economic integration into global markets, reflected in significant growth in foreign direct investment (FDI) inflows. Since the start of the accession negotiations between Turkey and the EU in 2004, FDI activity has increased dramatically, making it a home for a large number of MNEs (Mellahi et al. 2011). The total FDI stock increased nearly eight times from US\$ 19.2 billion in 2000 to US\$ 152.4 billion as of 2012 (Republic of Turkey - Ministry of Economy 2013b). Overall, the characteristics of the Turkish economy with significant stocks of FDI make it an interesting case to examine the nature of HRM practices and also to explore the HRM-performance link in MNE subsidiaries there. 
At the broader comparative level, as an emerging country on the periphery of Europe, Turkey (along with many other economies in the wider developing world) is characterized by both fluidity and weak inter-coupling in institutional forms (see Wood and Lane 2012). Such contexts may provide MNEs with a wider range of opportunities to pioneer new practices and/or adopt innovations more at odds with national norms than might be the case within more mature market settings; at the same time, the transposition of new practices may not be effective when removed from the supports of the original institutional environment where they were conceived. This may both facilitate the adoption of HPWS, yet constrain their effectiveness. Hence, although the findings of the study are specific to a particular setting, they may serve as the basis for future comparative research aimed at drawing out common practices and outcomes across the European periphery, and in comparing such contexts with mature liberal or coordinated market economies characterized by more developed and comprehensive institutional coverage.

\section{Hypotheses Development}

Owing to the fact that there is no universal agreement on what constitutes HPWS, our selection of HRM practices for this study builds on Fey et al.'s (2009) list of HRM practices (see also Björkman et al. 2007; Minbeava et al. 2003). A comprehensive discussion of the process of HRM practices selection is provided in Fey et al. (2009). The practices selected emerged from a thorough review as the six most often studied HRM practices (Fey et al. 2009, p. 692). Thus, these practices appear as the most commonly utilized measures of HPWS in the western context. We intend to explore how their deployment impacts on organizational performance in the Turkish context. Below we develop the hypotheses on the associations between HRM practices and organizational performance in the Turkish context.

\section{Employee Training}

Human capital theory emphasizes the impact of variation in employee skills on performance. Empirical research has identified the positive association of employee training on organizational 
outcomes (Lowry et al. 2002; Becker 1975; Wright et al. 1994; Tannenbaum et al. 1991; Saks 1995). For instance, training is positively associated with job attitudes, and negatively associated with turnover intentions (Saks 1995). Training and development additionally represents an important intervention in increasing individual employee skills and performance (Russell et al. 1985; Delaney and Huselid 1996). Pfeffer (1998) argues that investment in training constitutes a defining 'best' practice; indeed, training has been used as a measure in a number of other performance studies (e.g., Fey et al. 2000; Huselid 1995; MacDuffie 1995). The impact of training on both individual employee performance and aggregate organizational performance is likely to be particularly significant in Turkey owing to relatively low education levels in Turkey (Tanova and Nadiri 2005).

Training has also been linked with employee effectiveness, with employees considering the availability of training as a signal of being valued by the organization (Noe 1986), resulting in a positive impact on job satisfaction and motivation (Bartlett 2001; Kuvaas and Dysvik, 2010; Lowry et al. 2002; Caldwell et al. 1990). This effect may be particularly pronounced in MNE subsidiaries in Turkey for two key reasons; first, given the rapid rate of change in the Turkish economy and technological advancement, employees constantly feel the need to upgrade their skills to hold their positions in the labour market. Second, as argued by Aycan (2006, p. 127) "training and development opportunities are among the most motivating factors" in Turkey especially for the young workforce (Aycan and Fikret-Pasa 2003). Finally, there is an emerging consensus that training has a positive impact on organizational financial performance (Tharenou et al. 2007; Black and Lynch 1996; García 2005). Based on the above, we propose that:

Hypothesis 1: The use of employee training is positively related to managerial perceptions of MNE Turkish subsidiary outcomes in terms of (a) employee skills and education, (b) employee effectiveness, and (c) organizational financial performance. 


\section{Competence-based Performance Appraisal and Career Development}

Performance appraisal is generally considered integral to a firm's HRM system, particularly in facilitating the classification of individual performance levels and individual skills gaps (Locke et al. 1990). Competence-based performance appraisal systems provide employees with feedback that help them enhance their abilities and performance, and hence are argued to have a positive impact on employee's skills and abilities (Fey et al. 2009, p. 694; see also Wright et al. 1999). Thus, we propose that competence based performance appraisal is positively associated with employees' skills and abilities.

Turning to employee effectiveness, the role of HRM practices in influencing the motivation of employees and commitment is increasingly recognized (Fey et al. 2009). Theoretically, social exchange theory suggests that investment in people results in reciprocated positive work behaviours (Cropanzano and Mitchell 2005; Kuvaas and Dysvik 2010). Hence employees becoming pro-socially motivated, with the result that they desire to expend effort to benefit the organization (Kuvaas and Dysvik 2009). Finally, there are a number of recent studies in nonwestern countries that report a positive correlation between performance appraisal and organizational performance (Katou and Budhwar 2006). Thus we propose that:

Hypothesis 2: The use of competence-based performance appraisal is positively related to managerial perceptions of MNE Turkish subsidiary outcomes in terms of (a) employee skills and education, (b) employee effectiveness, and (c) organizational financial performance.

\section{Performance-based Compensation}

High reward contingent on performance has long been considered a key part of HPWS. While contingency approaches would suggest a more nuanced treatment of reward appropriate to the organization's strategy, it is clear that reward and performance-based compensation in particular, offer the potential alignment of employee behaviour with organizational goals. Indeed, 
performance-based compensation is identified as the single strongest predictor of firm performance in Delery and Doty's (1996) study. Similarly, empirical research points to a positive correlation between performance-based compensation and employee effectiveness (see Lawler 1981; Milkovich and Newman 1996; Fey et al. 2009). Thus, we propose that:

Hypothesis 3: The use of performance-based compensation is positively related to managerial perceptions of MNE Turkish subsidiary outcomes in terms of (a) employee skills and education, (b) employee effectiveness, and (c) organizational financial performance.

\section{Merit-based Promotion}

Merit-based promotion is considered indicative of an emphasis on internal labour markets and internal career development within organizations. Indeed, the availability of internal career opportunities is associated with increased employee effectiveness in terms of organizational commitment and motivation of employees, owing to the perception that there exist career opportunities (Guest 1997). It is also important in engendering a sense of justice and fairness among employees (Fey et al. 2000). As Pfeffer (1998) notes, employment security is important in sending employees a message that they have a long-term future with the organization (Aycan and Fikret-Pasa 2000).

Merit-based promotion also facilitates the retention of highly skilled employees. Given the above arguments regarding the link between employees' skills and abilities and organizational performance, we suggest that merit-based promotion enhances firm's financial performance. This leads to our fourth hypothesis:

Hypothesis 4: The use of emphasis on merit-based promotion is positively related to managerial perceptions of MNE Turkish subsidiary outcomes in terms of (a) employee skills 
and education, (b) employee effectiveness, and (c) organizational financial performance.

\section{Internal Communication}

Although information sharing is considered central to the reversal of the key features of the Taylorism in the HPWS model (see Wood 1999), there is limited research on the link between communication and organizational outcomes (Croucher et al. 2006). However, it can be argued that effective internal communication results in higher level of trust between workers and management, and facilitates team working through providing employees with information on which they can base their suggestions for improvements in business processes (Pfeffer 1998). Thus we propose the following hypothesis:

Hypothesis 5: The use of internal communication is positively related to managerial perceptions of MNE Turkish subsidiary outcomes in terms of (a) employee skills and education, (b) employee effectiveness, and (c) organizational financial performance.

\section{Employee Empowerment}

Involving employees in decision-making or employee empowerment and team working have also been shown to positively impact on organizational performance (Arthur 1994; MacDuffie 1995). As a non-hierarchical mode of operation, they may increase employee commitment to the organization (Fey et al. 2000). Specifically, they increase the potential for employees to broaden their skill set, suggesting that empowerment should have a positive impact on employee skills and abilities. Whilst this is theoretically premised on Western perspectives of the employment relationship, Turkish society is characterized by a high power distance with strong collectivist tendencies (Hofstede 1980). The hierarchical social structure of Turkey that emphasizes respect for superiors where subordinates tend to accept their lower positions in the organizational 
hierarchy may suggest that empowerment may not have a positive impact on performance. However, we argue that owing to the nature of the workforce who chose to work in MNE subsidiaries who may have aspirations and preferences more aligned with their Western counterparts than those working in more peripheral areas of the economy (Aycan and Fikret-Pasa 2000). Hence, combined with the deprivation hypotheses identified above, it could be argued that employee empowerment will positively impact on organizational outcomes. Thus, we propose that:

Hypothesis 6: The use of employee empowerment is positively related to managerial perceptions of MNE Turkish subsidiary outcomes in terms of (a) employee skills and education, (b) employee effectiveness, and (c) organizational financial performance.

\section{HRM Strategy-Fit}

There is no consensus on the linkage between internal fit and organizational performance $-\mathrm{a}$ limitation in part due to the difficulty in codifying what constitutes "good fit" (Becker and Gerhart 1996). This approach may be particularly appropriate in the Turkish context where given shifts - and volatility - in the political and economic climate there, organizations may find it difficult to formulate long term plans (Aycan 2001; Glaister et al. 2008). However, it could be argued that aligning HRM policies with the firm's strategic orientation may result in improved outcomes from the firm and employees alike.

Hypothesis 7: The alignment of HRM policies with the overall strategic orientation of the organization is positively related to managerial perceptions of Turkish MNE subsidiary outcomes in terms of (a) employee skills and education, (b) employee effectiveness, and (c) organizational financial performance. 
The conceptual framework of the hypothesized relationships is delineated in Fig. 1.

\section{[Insert Figure 1 over here]}

\section{Research Methods \\ Sample and Data Collection}

The sampling frame for MNE subsidiaries in Turkey was drawn from the database of a government agency, General Directorate of Foreign Investment (GDFI). All foreign equity ventures operating in Turkey are recorded by the GDFI, which acts as a one-stop agency for implementing the regulations concerning foreign direct investment. As of May 2008, the database of GDFI consists of 19,909 FDI firms (GDFI 2008). From the original list of 19.909 FDI firms in the database, a new dataset was compiled based on the capital value of the subsidiary and the proportion of foreign equity shareholding. Those ventures with capital value of less than one million USD were excluded. Most of these firms are owned by a single person or established by means of ordinary partnerships. For the purposes of this survey, it was not considered feasible to include these firms in the sampling frame. This study also uses the 10 per cent and 90 per cent cut-off points to capture the alternative ownership structures. The investments with foreign ownership of less than 10 per cent are considered to be portfolio investments and were excluded from the database. A venture is defined as a JV when foreign equity ownership ranges from 10 per cent to 90 per cent, while a venture with foreign equity shareholding of over 90 per cent is considered to be a WOS. This range is consistent with the definition of a JV used by the US Department of Commerce. Park and Ungson (1997), Hladik (1985) and Demirbag et al. (2007) also followed the same definitions.

Based on a random sampling selection procedure, a total of 500 firms was generated and constituted the sample for the study. A questionnaire and a covering letter were posted to the $\mathrm{CEO}$ of each member company with a letter requesting that $\mathrm{s} / \mathrm{he}$, or her/his senior executive in charge of HRM within the organization, should complete it. After one reminder, a total of 148 
usable questionnaires were returned, representing a response rate of $29.6 \%$. The distribution of respondents were $22.9 \%$ CEOs (e.g., chairman, general manager), $8.8 \%$ deputy general managers, 51.4\% HRM managers and $16.9 \%$ planning executives and other senior executives in charge of HRM practices. ANOVA tests were used to examine the differences among means for the respondent categories. No significant differences $(p>0.1)$ were detected. Given the level of responsibility of respondents, the findings provide a good reflection of senior management's views on the nature of HRM practices. The responding companies were also compared across the main characteristics of the sample such as industry type and geographical location and again showed no systematic differences $(\mathrm{p}>0.1)$.

The sample is composed of relatively large firms given the scale of the Turkish economy, with only $15.5 \%$ of the firms classified as small size (fewer than 50 employees). The sample of 148 MNE subsidiaries had mean number of employees of 1,221 , while the mean number of employees for their foreign parents was 44,509. The average age of sample firms was 19.22 years. Of this sample, $88(59.5 \%)$ were WOSs and 60 (40.5\%) were JVs. Regarding the establishment mode of subsidiary adopted by the MNE in the formation stage of subsidiary, 115 (77.7\%) were established by setting up new ventures (greenfield investments) and the remaining $33(22.3 \%)$ were formed by full or partial acquisition of existing local firms.

The distribution of the sample in terms of the country of origin of the MNE subsidiaries are as follows: USA (29.6\% of the total), Germany (22.3\%), UK (13.5\%), France (4.1\%), Italy (4.1\%), Netherlands (4.1\%), Switzerland (4.1\%), other EU countries (6.7\%) and Asian countries (11.5\%). The breakdown of the sample in terms of the sector of operation is as follows: industrial, automotive and electrical equipment, 5.4\%; food, textile and paper, 6.1\%; metal, wood, leather and glass, $4.1 \%$; chemical and pharmaceuticals, $8.8 \%$; other manufacturing, $8.8 \%$; wholesale and retail trade, 12.2\%; computer and engineering services, $6.1 \%$; financial services and consultancy, 14.9; hospitality and leisure services, $16.2 \%$; and other services, $17.6 \%$.

The sample is a random one, but appears to be representative of the population. For example, the majority of the sample firms (67\%) are in services, which is consistent with the 
actual sectoral distribution of FDI firms in Turkey as of 2008 (64.7\%). A similar pattern is also observed regarding the country of origin distribution of sample firms when compared with that of the overall population of FDI firms. For instance, FDI firms from EU countries accounts for $\% 54.8$ of the sampled firms, which broadly mirrors the actual distribution of all FDI firms from the same group of countries in Turkey as of 2008 (51.2\%). The characteristics of MNE subsidiaries are summarized in Table 1.

\section{[Insert Table 1 over here]}

Since the independent and dependent constructs are measured from the same source, it is possible that there will be common method variance (CMV) bias, which may contaminate all measures in the same direction (Podsakoff et al. 2003). Therefore, it is critical to assess the extent to which CMV bias is likely to affect the results. Following the statistical methods recommended by Podsakoff et al. (2003), CMV was tested through usage of the Harman's single factor test. All the observed variables were assigned to their respective latent construct and the fit indices for this model - i.e. the measurement model was compared to a new model where all the observed variables were assigned to a single latent construct. The single factor model was found to be far too poor with a chi-square/df value of 3.418 and RMSEA value of 0.128 compared to the actual measurement model (Chi-square/df value of 1.5 and RMSEA of 0.059) thereby establishes lack of a serious CMV bias.

\section{Operationalization of Variables}

The following subsections detail the operationalization of the variables used in the study. All of the measures used in the empirical analyses were drawn from previously administered questionnaires (e.g., Fey et al. 2000; Fey and Björkman 2001; Minbaeva et al. 2003; Björkman et al. 2007; Fey et al. 2009; Collings et al. 2010). The measurement of the study's constructs (along with the exact wording of the questions) and their sources are reproduced in Appendix. 


\section{Dependent Variable}

The subsidiary firm performance was treated as the dependent variable. It is generally recognized that it is difficult to select a single measure of firm performance. Previous studies have taken either a subjective or an objective approach to measuring performance. The subjective approach has been used extensively in empirical studies, based on executives' perceptions of performance, having been justified by several writers (Arino 2003; Delios and Beamish 2004; Geringer and Hebert 1991; Glaister and Buckley 1999). In line with these arguments, we did not only look at financial performance, but two other dimensions as well, as follows:

1. Employee skills and education (PERF1): Respondents were asked to indicate on a 7-point Likert-type scale, ranging from "far below average" through "average" to "far above average" and a "don't know" category, how they rate the performance of their subsidiary's employees relative to their major competitors on each of the following three criteria: overall ability, job related skills and educational level. An index measure composed of these three items captures the subsidiary's HRM performance in terms of employee skills and education $(\alpha=0.85)$.

2. Employee effectiveness (PERF2): Similarly, relying on a 7-point Likert-type scale an index was also used to rate the effectiveness ${ }^{1}$ of the subsidiary's employees relative to its competitors on the following five items: organizational level motivation, organizational commitment, job satisfaction, flexibility/adaptability and work effort $(\alpha=0.92)$ (see also Wright and Oldford $1993)^{2}$.

3. Organizational financial performance (PERF3): Respondents were asked to indicate on a 7point Likert-type scale, ranging from "definitely worse" through "about the same" to "definitely better" or "don't know", how their subsidiary had performed relative to its major competitors over the last 3 years on each of the following financial performance criteria: profit margin growth, sales growth and profit margin $(\alpha=0.88)$.

We recognize that managers represent a specific interest grouping, and that their perceptions will not be wholly reliable, and vary fundamentally with others within the firm (Gill 
and Johnson 2010, p. 194). In practical terms, this paper is actually based on three very distinctive types of information provided by managers. The first is perceptions of employee skills and capabilities. We recognize that an alternative approach would be to exclusive focus on asking managers to report on formal education and skill levels (e.g. proportion of the workforce with a particular qualification). However, this would not take account of informal, and more difficult to measure, skills and capabilities.

The second is employee effectiveness, which is measured by managerial perceptions of employee motivation, organizational commitment, job satisfaction, flexibility and work effort. In other words, this is a collective measure of the sum of employee effectiveness. It could be argued that managers are not always in the best position to comment on the real effectiveness of their workforce. It may be, for example, that managers simply blame their own shortcomings on 'ineffective' subordinates. It is quite possible that here, that in an environment characterized by poor industrial relations, managers may talk down the capacity and attributes of their workforce to justify low pay, and/or to explain a general climate of mistrust. Again, it could be argued that if managers perceive their workforce to be poorly motivated it is likely that this will bias their responses. Managers may naturally seek to rationalise poor industrial relations and hence, suboptimal organizational outcomes by blaming workers (Douglas 1995). However, as Aquino et al. (2001) note, blame is likely to result on revenge; that is, such a managerial approach is likely to become a self-fulfilling prophecy. Again, Bryson (2001) found that, based on the evidence of the UK Workplace Employment Relations Survey, characteristics such as the size of the firm and the industry, and specific sets of managerial practices, had a stronger effect on managerial perceptions of the general organizational climate than organization-specific industrial relations realities. In a stream of HRM literature, adopting the managers' perspective instead of that of the employees to determine HRM outcomes has also been considered as appropriate (Wright et al. 2001; Björkman et al. 2007; Klaas et al. 2012). As Wright et al. (2001, p. 113) argue, the firm's managers "are in the ideal position to make decisions regarding how to balance the desires of and returns to shareholders, customers, and employees". Hence, the use of key informants may still 
be valid as this research deals with managerial perceptions of the general organizational climate than individual levels of commitment, motivation and job satisfaction.

The third is perceptions of financial performance. As noted above, there is a broad body of literature that suggests that managerial perceptions of organizational performance are consistent with objective measures (Venkatraman 1990; Venkatraman and Ramajuman 1986; Dess and Robinson 1984; Geringer and Hebert 1991), and are superior in that they take better account of national variations in accounting standards (Day and Wensley 1988). In contrast, the usage of managerial perceptions of firm performance is a generally accepted approach. However, in our analysis, we estimate two models for each dependent variable, allowing for the possibility of fundamental differences between them. We similarly recognize that an employee survey would yield very different results, but, at least in part this would be due to workers being less likely to have at their disposal the same breadth of information on the organization as a whole as managers would. However, extending this study with a further, employee survey of the same organizations would represent an important future research priority. Hence, we recognize that, there is limited consistency as to the definition of organizational performance and its constituent components, within the existing literature, and that which contributes to performance outcomes may themselves exert influence in different ways. Insights into the latter might be best gained through more in-depth qualitative methods, which, whilst beyond the scope of the present research would again constitute a fertile area for future enquiry.

\section{Independent Variables}

The independent variables were measured as follows:

Employee training (TRAINING) was measured by two items including the number of days of formal training managerial and non-managerial employees receive annually $(\alpha=0.85)$.

Competence-based performance appraisal (PERF_APP) was measured by an index composed of three items. The first item measures the proportion of the employees that regularly receive a formal evaluation of their performance (in per cent), the second item measures the 
proportion of jobs where a formal job analysis has been conducted (in per cent), and the final item measures the proportion of new jobs for which a formal analysis of the desired personal skills/competencies/characteristics is carried out prior to making a selection decision (in per cent) $(\alpha=0.68)$.

Performance-based compensation (PERF_COMP) was measured by four items. Relying on a 5-point Likert scale (ranging from $1=$ not at all to $5=$ to a large extent) the first two items ask the respondents whether the subsidiary uses performance-based compensation and to what extent their compensation systems are closely connected with the financial results of the subsidiary. The third item captures whether pay is tied to individual performance, and the final item measures the extent to which differences in pay across employees in subsidiary represent differences in their contribution to the firm $(1=$ not at all to $5=$ to a large extent $)(\alpha=0.64)$.

Merit-based promotion (MERIT_PRO) was measured by an index composed of three items. The first two items ask the respondents to what extent upper-level vacancies are filled from within, and whether qualified employees have the opportunity to be promoted to positions of greater pay and/or responsibility within the subsidiary $(1=$ not at all to $5=$ to a large extent), while the third item measures whether the subsidiary places a great deal of importance on merit when making promotion decisions $(1=$ not at all to $5=$ to a large extent $)(\alpha=0.63)$.

Internal communication (INT_COMM) could be defined as the extent to which exchange of information occurs within the subsidiary and was measured by a scale composed of three items using 5 -point scales $(1=$ not at all to $5=$ to a large extent $)$. The items denote communication flows between (i) employees in different departments, (ii) non-managerial employees and managerial employees, and (iii) the HRM department and the top management team $(1=$ not at all to $5=$ to a large extent $)(\alpha=0.75)$.

Employee empowerment (EMPOWER) was measured by an index composed of three 5point scale items. The first two items measure the extent to which employee input and suggestions are highly encouraged, and are often implemented, while the third item measures 
whether employees' capabilities are viewed as the subsidiary's main source of competitive advantage $(1=$ not at all to $5=$ to a large extent $)(\alpha=0.71)$.

HRM-strategy fit (HRM_FIT) was measured through an index consisting of three 5-point scales $(1=$ not at all to $5=$ to a large extent). Respondents were asked the following questions: (i) to what extent do their firms make an explicit effort to align business and HRM/personnel strategies? (ii) to what extent is the HRM/personnel department involved in the strategic planning process? (iii) to what extent are HRM/personnel managers viewed by those outside the function as partners in the management of the business and agents for change $(\alpha=0.85)$ ?

\section{Control Variables}

Several control variables were included to account for subsidiary-level, parent-level and industrylevel effects.

To control for subsidiary-level effects, we included subsidiary age, subsidiary size, organizational and establishment mode of subsidiary.

Subsidiary age (AGE) was included as a control variable, since firms with more business experience have gone through a learning process concerning how to conduct business in the Turkish context. We expect a positive relationship between subsidiary age and HRM outcomes as well as organizational financial performance.

Subsidiary size (LN_SIZE) was also controlled for as large firms may allocate more resources to the business and may tend to have more developed HRM systems and processes. Then a positive relationship may exist between subsidiary size, and HRM outcomes and organizational financial performance. Subsidiary size was measured as the logarithm of the total number of employees in the subsidiary.

Organizational mode of subsidiary (ORG_MODE) was measured by a dummy variable that takes the value of 1 if the subsidiary is a JV or 0 if it is a WOS.

Similarly, establishment mode of subsidiary (EST_MODE) was measured by a dummy variable that was assigned a value of 1 for greenfield ventures, and 0 for acquisitions. 
Parent-level effects were captured by the following control variables which included foreign parent size, the extent of foreign parent diversity and the nationality of MNE subsidiaries.

Foreign parent size (LN_FPSIZE) was measured using the logarithm of the total number of employees in the foreign parent firm.

Foreign parent diversity (DIVER) was measured using Rumelt's (1974) categories, i.e. single business, dominant business, related business, and unrelated business, an ordinal variable was created that takes the value from 1 to 4 to represent each category, respectively.

To control for the country of origin effect, the overall sample of MNE subsidiaries was partitioned into three groups. The first group consists of subsidiaries established by MNEs from the USA and the UK; the second group includes subsidiaries established by continental European MNEs; and the third group includes subsidiaries formed by Asian MNEs. The sample was partitioned, therefore, according to the geographical proximity of the MNEs to the Turkish market and the relatively similar business orientations of the firms in each group of countries stemming mainly from institutional factors. In this sense, the UK-based MNEs are liberal market economies and considered as adhering more to Anglo-American business practices than are other western European MNEs that are predominantly characterized as coordinated market economies despite the fact that the UK is an important member of EU with its economy being closely tied to the EU.

To control for industry variations, industry dummies were created for nine industry categories: (1) industrial, automotive and electrical equipment (IND_ELECT); (2) food, textile and electrical equipment (FOOD_TEXT); (3) metal, wood, leather and glass (METAL_WOOD); (4) chemical and pharmaceuticals (CHEM_PHAR); (5) other manufacturing (OTH_MANUF); (6) wholesale and retail trade (TRADE); (7) computer and engineering services (COMP_ENG); (8) financial services and consultancy (FIN_CONS); and (9) hospitality and leisure services (HOSP_LEIS). 


\section{Analysis and Results}

Table 2 shows descriptive statistics and correlation coefficients of independent variables in the study. The pairwise correlations do not seem to present serious multicollinearity problems for the multivariate analysis, as none of the variables have correlation coefficients above 0.50 (Hair et al. 2006).

\section{[Insert Table 2 over here]}

We run multiple regression analysis in order to test the study's hypotheses. Despite merits of essentially superior structural equation modelling (SEM) methodology that can examine a series of dependence relationships simultaneously (Hair et al. 2006), we have decided to stick to a traditional regression-based approach. To this end, a series of regression models were estimated with the dependent variable being each of the subsidiary HRM performance outcomes: employee skills and education (PERF1), employee effectiveness (PERF2) and organizational financial performance (PERF3). The effects of independent variables on each of the dependent variables of PERF1, PERF2 and PERF3 are shown in Tables 3 to 5, respectively. As noted above, two models were estimated for each dependent variable. As the first step, all three sets of control variables were entered (Model 1 in Tables 3 to 5). Among these variables, while some of the industrial dummies had only modest effects on any of the MNE subsidiary performance outcomes, both subsidiary and parent-level control variables were found to have no significant effects.

The effects of the hypothesized variables were then tested in Model 2 where all independent variables along with control variables were tested, as shown in Tables 3 to 5, respectively. The $\mathrm{F}$ statistics in all three regression equations (Model 2 in Tables 3 to 5) are significant and hence are useful for explanation purposes. For each of the regression models, variance inflation factors (VIF) were examined to determine the existence of multicollinearity. None of the VIF scores were above 2.9, indicating that multicollinearity is not a problem with these data (Hair et al. 2006). 


\section{[Insert Tables 3, 4 and 5 over here]}

Some partial support was noted for H1b concerning the effect of TRAINING on HRM performance outcome of employee effectiveness (PERF2), as the coefficient of TRAINING is positive and significant $(\mathrm{p}<0.1)$ in Table 4. No support, however, was found for H1a and H1c regarding the effect of employee training (TRAINING) on HRM performance outcome of employee skills and education (PERF1), and organizational financial performance (PERF3).

The coefficients of competence-based performance appraisal (PERF_APP) in Model 2 in Tables 3 and 4 are positive and significant $(\mathrm{p}<0.05)$ indicating that there exits some support for $\mathrm{H} 2 \mathrm{a}$ and $\mathrm{H} 2 \mathrm{~b}$ with respect to the effect of PERF_APP on HRM-related MNE subsidiary performance outcomes of PERF1 and PERF2. The degree of support for H2c, however, becomes stronger as the coefficient of PERF_APP in Model 2 in Table 5 is positive and significant $(\mathrm{p}<0.01)$, indicating that PERF_APP has a strong positive impact on the perception of MNE subsidiary performance in terms of organizational financial performance.

$\mathrm{H} 3 \mathrm{a}$ is not supported in that the coefficient of performance-based compensation (PERF_COMP) in Model 2 in Table 3 is not significant, indicating that there is no relationship between PERF_COMP and the perception of HRM-related MNE subsidiary performance outcome of PERF1. Some support, however, was found for H3b, as the coefficient on PERF_COMP in Model 2 in Table 4 is positive and significant $(\mathrm{p}<0.05)$, suggesting that PERF_COMP has a positive impact on the perception of MNE subsidiary performance outcome of PERF2. Moreover, only partial support was found for $\mathrm{H} 3 \mathrm{c}$ with regard to the impact of PERF_COMP on PERF3, as shown in Model $2(\mathrm{p}<0.1)$ in Table 5.

While there is partial support for H4a (Model 2 in Table 3), a strong support was found for H4b (Model 2 in Table 4). No support, however, was noted for H4c (Model 2 in Table 5).

The coefficients of internal communication (INT_COMM) on both PERF1 and PERF2 are significant $(\mathrm{p}<0.01)$, providing a good deal of support for H5a and H5b, respectively. No support, however, was noted for H5c in that the coefficient of INT_COMM is not significant. 
Strong support was found for H6b positing that employee empowerment (EMPOWER) had a positive and significant impact on HRM-related performance outcome of employee effectiveness (Model 2 in Table 4). In contrast, there is no support for H6a and H6c in that EMPOWER had no significant impact on the perception of MNE subsidiary performance outcomes of PERF1 and PERF3.

Finally, the coefficients of HRM-strategy fit (HRM_FIT) on all three MNE subsidiary performance outcomes of PERF1, PERF2 and PERF3 are insignificant providing no support for H7a, H7b and H7c (Tables 3 to 5).

\section{Discussion, Conclusion and Implications}

Although HPWS have been applied widely by MNEs, their impact on performance is still not fully understood. The result of extensive empirical research on the association between the practice of HPWS and organizational performance in non-western contexts is inconclusive and contradictory. Thus, continued efforts to understand the association between HPWS and performance is highly warranted. This study examined the association between HPWS and organizational outcomes in subsidiaries of western MNEs in Turkey. The extant literature and recent empirical studies suggest that HPWS have become "taken for granted" and hence institutionalized in the global economy (Pudelko and Harzing 2007; Lawler et al. 2010), thus, we expected to see a positive association between HPWS and three organizational outcomes, namely employee skills and education, employee effectiveness, and organizational financial performance.

Our findings provide a degree of support for the positive association between HPWS and our organizational performance measures; however the picture is a nuanced one. Our findings do suggest a convergence of HPWS in terms of their utilization in MNE subsidiaries, with strong evidence of the deployment of HPWS, with the exception of competence-based performance appraisal. Why is this not the case with the latter? Gooderham et al. (2006) argue that the latter represents a defining embodiment of calculative HRM, a top down, shareholder-orientated approach that has little in common with more affirmative or cooperative approaches to HPWS. 
Apart from this, it does seem true that MNEs are engaged in diffusing HPWS within their subsidiaries. As predicted by Morgan (2012), their presence in multiple institutional domains means that they are less bound by nationally embedded ways of doing things, and owing to inherently weaker local ties, are better equipped to modernize. This finding is consistent with some recent contributions (Pudelko and Harzing 2007). MNE's capacity to diffuse HPWS to the Turkish context may be partly explained by Aycan and Fikret-Pasa's (2000) assertion that younger workers, who opt to work in MNEs, are more receptive to Western innovations in management practice. Our hypotheses on the positive association between internal communication, employee empowerment, and merit-based promotion on employee effectiveness are strongly supported. Further, the hypothesis related to performance-based compensation received moderate support, while the positive association between employee training and employee effectiveness was only partially supported. Thus, all of the HPWS which employees experience are to some degree linked to improved employee effectiveness. Given that many of these practices differ significantly from Turkish managerial and traditions, this seems to resonate with the deprivation hypothesis put forward from the GLOBE study. This suggests that individuals hold views on what "should be" based on their experience, in other words, that they seek and value what they do not have (Javidan et al. 2006, p. 902). In summary, our findings suggest that employee effectiveness is enhanced through the deployment of HPWS.

The impact of HPWS on other outcome variables examined in this study is far more equivocal. The hypothesized linkage between HPWS on employee skills and education was not confirmed to any significant degree. Specifically, only internal communication emerged as having a strong linkage with employee skills and education, with relatively moderate support for the role of competence-based appraisal. None of the other HPWS displayed any significant impact on employee skills and education. Perhaps the training provided by subsidiaries of MNEs in Turkey was not relevant to the local context, and therefore was not effective in developing the skills and education of employees in the host country. Given that we measured training and education performance relative to competitors, it is possible that MNEs provided less training 
than local Turkish firms. This may be because Turkey is generally perceived as a strong emerging modern country but education levels in the country tend to be relatively low (Tanova and Nadiri 2005) in comparison to western norms. Therefore, MNEs may overestimate the underlying skills and abilities of the local workforce and, thus, may find their HPWS initiatives on expectations that employee skills are far higher than in fact they are. It may also, underscore the extent to which training, not only being highly context specific, is also an ambiguous measure: firms with very low value added approaches to people management may be forced to engage in a great deal of basic induction training as a result of high staff turnover rates (Goergen et al. 2012). In contrast, firms engaging in higher value added approaches may spread informal training interventions over many years; as such firms are more desirable employers, staff turnover rates are likely to be lower in any event, particular in settings where good jobs are relatively scarce, making both induction less important, and informal, non-certified firm specific capabilities more so (see Goergen et al. 2012).

The findings are even starker in terms of the association between HPWS and financial performance of MNE subsidiaries in Turkey. The results show that with the exception of competence-based performance appraisal and performance-based compensation, HPWS did not foster high financial performance. Lillrank (1995) argues that efficient transfer of best practices over cultural and institutional borders is a slow and complicated process. Therefore, one plausible reason for this could be that more time is needed for HPWS to be accepted and efficiently implemented within the Turkish context. In particular, HPWS may need to be adapted to the local Turkish context in order to foster high financial performance. This may also be the case simply because low value added HRM paradigms may be quite lucrative in the short term in settings where institutional arrangements are more fluid and less tightly coupled. In contrast, higher value ones are more likely to yield advantages in the longer term, and/or indirectly in the form of more productive and, hence, better rewarded workers and, consequently, more developed consumer markets; however, such approaches need effective institutional restraints to deter firms from the immediate rewards of excessive short-termism (see Boyer 2012). 


\section{Managerial Implications}

Overall, our results suggest that while MNEs may promote HPWS - and this study provides further evidence of their continued diffusion into emerging markets - their impact on subsidiary financial performance in the Turkish context appears to be very limited. While employees seem to be relatively highly motivated by HPWS, ultimately this motivation does not translate into improved subsidiary financial performance. Our findings in relation to employee skills and education may be important in interpreting this finding. The failure of HPWS may be due at least in part to the failure of MNEs to adapt their practices to fit in with local institutional realities, and that HPWS may be less viable in emerging country settings, where institutional coverage is weaker or more fluid. It is also harder for outsiders to accurately cost the worth of the existing individual and collective capabilities of workforces (Aoki 2010). This means that new interventions may be unnecessary, redundant, or undermine existing advantages. Again institutional fluidity make it difficult to innovate through building on existing capabilities and ties; existing advantages they confer may be eroding without necessarily being replaced by new or comparable ones (see Streeck 2009). Using the example of employee skills and education, arguably MNEs failed to adequately recognize the low level of attainment of the workforce in deploying HPWS which were developed in the context of a relative well educated workforce in the western context. Hence it does appear that HRM remains a function where localization of practices is particularly important.

\section{Limitations and Future Research}

While this study provides useful insights to the HRM-performance link in MNE subsidiaries, its limitations should also be acknowledged. Relying on managerial perceptual data introduces biases through increased measurement error and the potential for mono-method bias, but, by the same measure, it is by no means unprecedented to utilize such measures. Although it would possible to make use of objective measures of organizational performance, gaining access to such 
measures both at parent and subsidiary levels (as adverse to overall company data) is a major obstacle. It is also important to note that recent empirical work (Wall et al. 2004) has confirmed that objective and subjective measures of company financial performance were positively correlated. Finally, we recognize that managers have interests and agendas of their own, and may not always be reliable sources of information on employee effectiveness, even if blame attribution will tend to make the latter worse (Aquino et al. 2001). Hence, we recognize that extending the study through the usage of an employee survey and/or supplementing it through more in-depth methods would represent a fertile area for future enquiry; this may also generate crisper and more definitive results. The use of relative measures (e.g. to major competitors) might also be a cause for the unexpected results.

Another limitation of this study is that the study may have suffered from potential CMV bias, as the data on HPWS and on organizational performance was provided by the same respondent. Collecting data from multiple informants and company level objective data (such as absenteeism, employee turnover), or conducting longitudinal research would help researchers to circumvent this CMV problem. While we addressed the CMV bias through a post hoc Harman's single factor test, there are several other post hoc procedural remedies including possibly a more complex model specification (including interaction and non-linear terms), and explicitly partialing out or controlling for CMV statistically (see Chang et al. 2010 for guidelines), which should be attempted in future research to deal with CMV problem.

We also need to recognize the apparent merits of more superior multivariate techniques such as SEM over traditional regression analysis. These techniques are particularly useful in testing research models that consist of multiple equations involving dependence relationships. Of these techniques, partial least squares (PLS) has a growing popularity in recent years and been widely used as an alternative to SEM in management research due to its distinctive methodological features (Hair et al. 2012; Henseler et al. 2009). So, it would be particularly useful to employ SEM/PLS in future research. 
Our study looked at the extent to which HPWS practices were used by subsidiaries of MNEs in Turkey. The study did not consider how well the practices were implemented. Research that goes beyond "the level of spread" of HPWS and examines their implementation - how the practices are cascaded down the organization - may shed some important light on the lack of association between the practices and organizational performance in Turkey. Again, research on the institutional barriers to efficient implementation of HPWS in Turkey may cast further light on the appropriateness of such practices in emerging market contexts. 
Acknowledgements: We would like to thank Editor Jochaim Wolf and three anonymous reviewers for their extremely helpful and insightful comments, which enabled us to greatly improve on earlier iterations of this paper.

\section{Endnotes}

1 In addition to these dimensions, effectiveness will also represent a product of individual employee physical and psychological well being, issues which are beyond the scope of the study (Turner 1933, pp. 578-579).

2 It is important to point out that we did not ask top management/HR manager to rate individual motivation, commitment and job satisfaction levels but rather asked for their perception of the overall levels of employee effectiveness in the organization.

\section{References}

Agartan, K. (2010). Turkey's accession to the European Union and the Turkish labour movement. European Journal of Turkish Studies [Online], 11. Uploaded 21 March 2013. URL: http://ejts.revues.org/4297.

Almond, P., Edwards, T., Colling, T., Ferner, A., Gunnigle, P., Müller-Camen, M., Quintanilla, J., \& Wachter, H. (2005). Unraveling home and host country effects: An investigation of the HR policies of an American multinational in four European countries. Industrial Relations: A Journal of Economy and Society, 44(2), 276-306.

Amable, B. (2003). The diversity of modern capitalism. Oxford: Oxford University Press.

Aoki, M. (2010). Corporations in evolving diversity: Cognition, governance and institutions. Oxford: Oxford University Press.

Aquino, K, Tripp, T., \& Bies, R. (2001). How employees respond to personal offense: The effects of blame attribution, victim status, and offender status on revenge and reconciliation in the workplace. Journal of Applied Psychology, 86(1), 52-59.

Arino, A. (2003). Measures of strategic alliance performance: An analysis of construct validity. Journal of International Business Studies, 34(1), 66-79.

Arthur, J.B. (1994). Effects of human resource systems on manufacturing performance and turnover. Academy of Management Journal, 37(3), 670-687.

Aycan, Z. (2001). Human resource management in Turkey: Current issues and future challenges. International Journal of Manpower, 22(3), 252-260.

Aycan, Z. (2006). Human resource management in Turkey in Budhwar, P., \& Mellahi, K. (Eds.). Human Resources Management in the Middle East. Routledge: London: 160-179.

Aycan, Z., \& Fikret-Pasa, S. (2000). Leadership preferences, career choices and work motivation in Turkey: A national profile and regional differences", paper presented at $15^{\text {th }}$ International Congress of the International Association of Cross-Cultural Psychology, USA.

Aycan, Z., \& Fikret-Pasa, S. (2003). Career choices, job selection criteria, and leadership preferences in a transitional nation: The case of Turkey. Journal of Career Development, 30(2), 129-144.

Aycan, Z., Kanungo, R.N., Mendonca, M., Yu, K., Deller, J., Stahl, G., \& Khyrsid, A. (2000). Impact of culture on human resource management practices: A 10 country comparison. Applied Psychology: An International Review, 49(1), 192-220.

Bartlett, K.R. (2001). The relationship between training and organizational commitment: A study in the health care field. Human Resource Development Quarterly, 12(4), 325-352. 
Becker, G.S. (1975). Human capital, a theoretical and empirical analysis with special reference to education, (2 ${ }^{\text {nd }}$ Ed.). New York: Colombia University Press.

Becker, B., \& Gerhart, B. (1996). The impact of human resource management on organizational performance: Progress and prospects. Academy of Management Journal, 39(4), 779-801.

Björkman, I., Fey, C.F., \& Park, H.J. (2007). Institutional theory and MNC subsidiary HRM practices: Evidence from a three country study. Journal of International Business Studies, 38(3), 430-445.

Black, S.E., \& Lynch, L.M. (1996). Human-capital investments and productivity, American Economic Review, 86(2), 263-267.

Bondy, K., \& Starkey, K. (2014). The Dilemmas of Internationalization: Corporate Social Responsibility in the Multinational Corporation. British Journal of Management, 25(1), 422.

Boselie, P., Dietz, G., \& Boon, C. (2005). Commonalities and contradictions in HRM and performance research. Human Resource Management Journal, 15(3), 67-94.

Boxall, P. (2013). Mutuality in the management of human resources: assessing the quality of alignment in employment relationships. Human Resource Management Journal, 21(3), 317.

Boyer, R. (2012). Capitalizing on crisis: Review symposium. Socio-Economic Review, 10(2), 403-407.

Bowen, D.E., \& Ostroff, C. (2004). Understanding HRM-firm performance linkages: The role of the "strength" of the HRM system. Academy of Management Review, 29(2), 203-221.

Brewster, C., Wood, G., Croucher, R., \& Brookes, M. (2007). Collective and individual voice: Convergence in Europe? International Journal of Human Resource Management, 18(7): 1246-1262.

Brown, A.D., \& Humphreys, M. (2002). Nostalgia and the narrativization of identity: A Turkish case study. British Journal of Management, 13(2), 141-159.

Bryson, A. (2001). Union effects on managerial and employee perceptions of employee relations in Britain. CEPDP, 494. Centre for Economic Performance, London, UK: London School of Economics and Political Science.

Caldwell, D.F, Chatman, J.A., \& O'Reilly, C.A. (1990). Building organizational commitment: A multifirm study. Journal of Occupational Psychology, 63(39, 245-261.

Chang, S.J., Witteloostuijn, A.V., \& Eden, L. (2010). From the editors: Common method variance in international business research. Journal of International Business Studies, 41(2), 178-184.

Collings, D., Demirbag, M., Mellahi, K., \& Tatoglu, E. (2010). Strategic orientation, human resource management practices and organizational outcomes: Evidence from Turkey. International Journal of Human Resource Management, 21(4), 2589-2613.

Cropanzano, R., \& Mitchell, M.S. (2005). Social exchange theory: An interdisciplinary review. Journal of Management, 31(6), 874-900.

Crouch, C., \& Voelzkow, H. (2004). Introduction. In Crouch, C., Le Galès, P., Trigilia, C., \& Voelzkow, H. (Eds.). Changing governance of local economies. Oxford: Oxford University Press, 1-10.

Croucher, R., Gooderham, P., \& Parry, E. (2006). The influences on direct communication in British and Danish Firms: Country, 'strategic HRM' or unionization. British Journal of Industrial Relations, 12(3), 267-286.

Day, G.S., \& Wensley, R. (1988). Assessing advantage: A framework for diagnosing competitive superiority. Journal of Marketing, 52(2), 1-20. 
Deeg, R., \& Jackson, G. (2008). Comparing capitalisms: Understanding institutional diversity and its implications for international business. Journal of International Business Studies, 39(4), 540-561.

Delaney, J.T., \& Huselid, M. (1996). The impact of human resource management practices on perceptions of organizational performance. Academy of Management Journal, 39(4), 949969.

Delery, J.E., \& Doty, D.H. (1996). Models of theorizing in strategic human resource management: Tests of universalistic, contingency, and configurational performance predictions. Academy of Management Journal, 39(4), 802-835.

Delios, A., \& Beamish, P.W. (2004). Joint venture performance revisited: Japanese foreign subsidiaries worldwide. Management International Review, 44(1), 69-91.

Demirbag, M., Glaister, K.W., \& Tatoglu, E. (2007). Institutional and transaction cost influences on MNEs' ownership strategies of their affiliates: Evidence from an emerging market. Journal of World Business, 42(4), 418-434.

Demirbag, M., Tatoglu, E., \& Glaister, K.W. (2008). Factors affecting perceptions of the choice between acquisition and greenfield entry: The case of Western FDI in an emerging market. Management International Review, 48(1), 1-34.

Dess, G.G., \& Robinson, R.B. (1984). Measuring organizational performance in the absence of objective measures: the case of the privately-held firm and conglomerate business unit. Strategic Management Journal, 5(3), 265-273.

DiMaggio, P.J., \& Powell, W.W. (1983). The iron cage revisited: Institutional isomorphism and collective rationality in organizational fields. American Sociological Review, 48(2), 147160.

Dore, R. (2000). Stock market capitalism: Welfare capitalism. Cambridge: Cambridge University Press.

Douglas, T. (1995). Scapegoats: Transferring Blame. London: Routledge.

Dyer, L., \& Reeves, T. (1995). Human resource strategies and firm performance: What do we know, and where do we need to go? International Journal of Human Resource Management, 6(3), 657-667.

Farndale, E., \& Paauwe, J. (2007). Uncovering competitive and institutional drivers of HRM practices in multinational corporations. Human Resource Management Journal, 17(4), 355375.

Fey, C.F., \& Björkman, I. (2001). The effect of human resource management practices on MNC subsidiary performance in Russia. Journal of International Business Studies, 32(1), 59-75.

Fey, C.F., Björkman, I., \& Pavlovskaya, A. (2000). The effect of human resource management practice on firm performance in Russia. International Journal of Human Resource Management, 11(1), 1-18.

Fey, C., Morgoulis-Jakoushev, S., Park, H.J., \& Björkman, I. (2009). Opening up the black box of the relationship between HRM practices and firm performance: A comparison of USA, Finland and Russia. Journal of International Business Studies, 40(4), 690-712.

Fikret Pasa, S., Kabasakal, H., \& Bodur, M. (2001). Society, organizations, and leadership in Turkey. Applied Psychology: An International Review, 50(4), 559-589.

Fisher, F.M., \& McGowan, J.J. (1983). On the issues of accounting rates of return to infer monopoly profits. American Economic Review, 73(1), 82-97.

García, M. (2005). Training and business performance: The Spanish case. International Journal of Human Resource Management, 16(9), 1691-1710.

GDFI (2008). Foreign investment report, July 2008. Ankara. 
Geringer, M.J., \& Hebert, L. (1991). Measuring performance of international joint ventures. Journal of International Business Studies, 22(2), 249-263.

Glaister, K.W., \& Buckley, P.J. (1999). Performance relationships in UK international alliances. Management International Review, 39(2), 123-147.

Glaister, K.W., Dincer, O., Tatoglu, E., Demirbag, M., \& Zaim, S. (2008). A causal analysis of formal strategic planning and firm performance. Management Decision, 46(3), 365-391.

Goergen, M., Brewster, C., Wood, G., \& Wilkinson, A. (2012). Varieties of capitalism and investments in human capital. Industrial Relations, 51(s1), 501-527.

Gooderham, P., Nordhaug, O., \& Ringdal, K. ( 2006). National embeddedness and calculative human resource management in US subsidiaries in Europe and Australia. Human Relations, 59(11), 1491-1513.

Goregenli, M. (1997). Individualist-collectivist tendencies in a Turkish sample. Journal of Cross Cultural Psychology, 28(6), 787-794.

Guest, D.E. (2011). Human resource management and performance: still searching for some answer, Human Resource Management Journal, 21(1), 3-13.

Guest, D.E. (1997). Human resource management and performance: A review and research agenda. International Journal of Human Resource Management, 8(3), 263-276.

Guthrie, J.P. (2001). High-involvement work practices, turnover and productivity: Evidence from New Zealand. Academy of Management Journal, 44(1), 180-190.

Hair, J.F., Black, W.C., Babin, B.J., Anderson, R.E., \& Tatham, R.L. (2006). Multivariate data analysis. 6th Ed., Upper Saddle River, New Jersey: Pearson.

Hair, J.F., Sarstedt, M., Ringle, C.M., \& Mena, J.A. (2012). An assessment of the use of partial least squares structural equation modelling in marketing research. Journal of the Academy of Marketing Science, 40(3), 414-433.

Hall, P., \& Soskice, D. (2001). An introduction to the varieties of capitalism. In Hall, P., \& Soskice, D. (Eds.), Varieties of capitalism: The institutional basis of competitive advantage. Oxford: Oxford University Press.

Hancke, B., Rhodes, M., \& Thatcher, M. (2007). Introduction. In Hancke, B., Rhodes, M., \& Thatcher, M. (Eds.). Beyond varieties of capitalism: Conflict, contradiction, and complementarities in the European economy. Oxford: Oxford University Press.

Heffernan, M., Flood, P., \& Liu, W. (2011). High performance work systems - international evidence of the impact of firms and employees. In A.W. Harzing and A.H. Pinnington, International Human Resource Management. Third edition, London: Sage.

Henseler, J., Ringle, C.M., \& Sinkovics, R.R. (2009). The use of partial least squares path modelling in international marketing. Advances in International Marketing, 20, 277-319.

Hladik, K.J. (1985). International joint ventures: An economic analysis of U.S. foreign business partnerships. Lexington MA: Lexington Books.

Hoftstede, G. (1980). Culture's consequences. Thousand Oaks, CA: Sage.

Huselid, M.A. (1995). The impact of human resource management practices on turnover, productivity and corporate financial performance. Academy of Management Journal, 38(3), 635-672.

Huselid, M.A., Jackson, S.E., \& Schuler, R.S. (1997). Technical and strategic human resource management effectiveness as determinants of firm performance. Academy of Management Journal, 40(2), 171-188.

IMF (International Monetary Fund) (2013). Report for selected countries and subjects. World Economic Outlook Database. Washington, D.C.: IMF. Accessed online, http://www.imf.org/external/pubs/ft/weo/2013/01/weodata/index.aspx. Accessed on $16 / 04 / 2013$. 
Javidan, M., House, R.J. Dorfman, P.W., Hanges, P.J., \& de Luque, M.S. (2006). Conceptualizing and measuring cultures and their consequences: A comparative review of GLOBE's and Hofstede's approaches. Journal of International Business Studies, 37(6), 897914.

Jessop, B. (2012). Rethinking the diversity and variability of capitalism: On variegated capitalism in the world market. In Lane, C., \& Wood, G. (Eds.). Institutions, internal diversity and change. London: Routledge.

Katou, A.A., \& Budhwar, P.S. (2006). Human resource management systems and organizational performance: A test of a mediating model in the Greek manufacturing context. International Journal of Human Resource Management, 17(7), 1223-1253.

Kaya, N. (2006). The impact of human resource management practices and corporate entrepreneurship on firm performance: Evidence from Turkish firms. International Journal of Human Resource Management, 17(12), 2074-2090.

Klaas, B.S., Semadeni, M., Klimchak, M., \& Ward, A-K. (2012). High-performance work system implementation in small and medium enterprises: A knowledge-creation perspective. Human Resource Management, 51(4), 487-510.

Kobayashi, N. (1982). The present and future of Japanese multinational enterprises. International Studies of Management and Organization, 12(1), 38-58.

Kostova, T., \& Roth, K. (2002). Adoption of an organizational practice by subsidiaries of multinational corporations: Institutional and relational effects. Academy of Management Journal, 45(1), 215-233.

Kostova, T., Roth, K., \& Dacin, T. (2008). Institutional theory in the study of MNCs: A critique and new directions. Academy of Management Review, 33(4), 994-1006.

Küskü, F., \& Zarkada-Fraser, A. (2004). An empirical investigation of corporate citizenship in Australia and Turkey. British Journal of Management, 15(1), 57-72.

Kuvaas, B., \& Dysvik, A. (2009). Perceived investment in employee development, intrinsic motivation and work performance. Human Resource Management Journal, 19(3), 217-236.

Kuvaas, B., \& Dysvik, A. (2010). Exploring alternative relationships between perceived investment in employee development, perceived supervisor support and employee outcomes. Human Resource Management Journal, 2(20), 138-156.

Lane, D., \& Myant, M. (2007). Introduction. In Lane, D., \& Myant, M. (Eds.), Varieties of capitalism in post-communist countries. London: Palgrave.

Lawler, E.E. (1981). Pay and organizational development. Reading, MA: Addison-Wesley.

Lawler, E.E. (1986). High-involvement management. Participative strategies for improving organizational performance. San Francisco, CA: Jossey-Bass Inc.

Lawler, E.E., Chen, S.J., Wu, P.C., Bae, J., \& Bai, B. (2010). High-performance work systems in foreign subsidiaries of American multinationals: An institutional model. Journal of International Business Studies, 42(2), 202-220.

Legge, K. (2005). Human resource management: Rhetorics and realities. Basingstoke: Palgrave Macmillan.

Lepak, D.P., Takeuchi, R., Erhardt, N.L., \& Colakoglu, S. (2006). Emerging perspectives on the relationship between HRM and performance. In Burke, R.J., \& Cooper, C.L. (Eds.), The human resources revolution: Why putting people first matters, 31-54, Elsevier.

Lillrank P. (1995). The transfer of management innovations from Japan. Organization Studies. 16(6), 971-989.

Lincoln, J., \& Kalleberg, A. (1990). Culture, control and commitment: A study of work organization in the United States and Japan. Cambridge: Cambridge University Press. 
Locke, E.A., \& Latham, G.P. and Smith, K.J. (1990). A theory of goal setting and task performance. Englewood Cliffs, NJ: Prentice-Hall.

Lowry, D.S., Alan Simon, A., \& Kimberley, N. (2002). Toward improved employment relations practices of casual employees in the New South Wales registered clubs industry. Human Resource Development Quarterly, 13(1), 53-70.

MacDuffie, J.P. (1995). Human resource bundles and manufacturing performance: Organizational logic and flexible production systems in the world auto industry. Industrial and Labor Relations Review, 48(2), 197-221.

Marchington, M., \& Grugulis, I. (2000). Best practice human resource management: Perfect opportunity or dangerous opportunity. International Journal of Human Resource Management, 11(6), 1104-1124.

Marescaux, E., De Winne, S., \& Sels, L. (2013). HR practices and affective organizational commitment: (when) does HR differentiation pay off? Human Resource Management Journal, 23(4), 329-345.

Marsden, D. (1999). A theory of employment systems. Oxford: Oxford University Press.

Mellahi, K., Demirbag, M., \& Riddle, L. (2011). Multinationals in the Middle East: Challenges and opportunities. Journal of World Business, 46(4), 406-410.

Metiu, A. (2006). Owning the code: Status closure in distributed groups. Organization Science, 17(4), 418-435.

Milkovich, G.T., \& Newman, J.M. (1996). Compensation (5th ed.). Homewood, IL: Irwin.

Minbaeva, D., Pedersen, T., Björkman, I., Fey, C.F., \& Park, H.J. (2003). MNC knowledge transfer, subsidiary absorptive capacity, and HRM. Journal of International Business Studies, 34(6), 586-599.

Monks, K., Kelly, G., Conway, E., Flood, P., Truss, K., \& Hannon, E. (2013). Understanding how HR systems work: the role of HR philosophy and HR processes. Human Resource Management Journal, 23(4), 379-395.

Morgan, G. (2012). International business, multinationals, and national business systems. In Wood, G., \& Demirbag, M. (Eds.). Handbook of institutional approaches to international business, 18-40, Cheltenham: Elgar.

Noe, R.A. (1986). Trainees' attributes and attitudes: Neglected influences on training effectiveness. Academy of Management Review, 11(4), 736-749.

Nolan, P., \& O’Donnell, K. (1995). Industrial relations and productivity. In P. Edwards (ed.) Industrial Relations. Oxford: Blackwell.

Park, S.H., \& Ungson, G.R. (1997). The effect of national culture, organizational complementarity and economic motivation on joint venture dissolution. Academy of Management Journal, 40(2), 279-307.

Paauwe, J., \& Boselie, P. (2003). Challenging 'strategic HRM' and the relevance of institutional setting. Human Resource Management Journal, 13(3), 56-70.

Pfeffer, J. (1998). The human equation: Building profits by putting people first. Boston: Harvard Business School Press.

Podsakoff, P.M., MacKenzie, S.B., Lee, J.Y., \& Podsakoff, N.P. (2003). Common method biases in behavioral research: A critical review of the literature and recommendations. Journal of Applied Psychology, 88(5), 879-903.

Psychogios, A., \& Wood, G. (2010). Human resource management in Greece in comparative perspective: Alternative institutionalist perspectives and empirical realities. International Journal of Human Resource Management, 21(14), 2614-2630. 
Pudelko, M., \& Harzing, A.W. (2007). Country-of-origin, localization, or dominance effect? An empirical investigation of HRM practices in foreign subsidiaries. Human Resource Management, 46(4), 535-559.

Republic of Turkey - Ministry of Economy (2013a). Foreign trade statistics. Accessed online, www.economy.gov.tr. Accessed on 16/04/2013.

Republic of Turkey - Ministry of Economy (2013b). Foreign direct investment statistics. Accessed online, www.economy.gov.tr. Accessed on 16/04/2013.

Ronen, S. (1986). Equity perception in multiple comparisons: A field study. Human Relations, 39(4), 333-345.

Rosenzweig, P.M. (2006). The dual logics behind international human resource management: Pressures for global integration and local responsiveness. In Stahl, G., \& Björkman, I. (Eds.) Handbook of Research in International Human Resource Management. Cheltenham: Edward Elgar, 36-48.

Rumelt, R. (1974). Strategy, structure and performance. Cambridge, MA: Harvard University Press.

Russell, J.S., Terborg, J.R., \& Powers, M.L. (1985). Organizational performance and organizational level training and support. Personnel Psychology, 38(4), 849-863.

Saks, A.M. (1995). Longitudinal field investigation of the moderating and mediating effects of self-efficacy on the relationship between training and newcomer adjustment. Journal of Applied Psychology, 80(2), 211-225.

Schneider, B. (2009). Hierarchical market economies and varieties of capitalism in Latin America. Journal of Latin American Studies, 41(3), 553-575.

Steers, R. (1975). Problems in the measurement of organizational effectiveness. Administrative Science Quarterly, 20(4), 546-558.

Streeck, W. (2009). Reforming capitalism: Institutional change in the German political economy. Oxford: Oxford University Press.

Tannenbaum, S.I., Mathieu, J.E., Salas, E., \& Cannon-Bowers, J.A. (1991). Meeting trainees' expectations: The influence of training fulfilment in the development of commitment, selfefficacy, and motivation. Journal of Applied Psychology, 76(6), 759-769.

Tanova, C., \& Nadiri, H. (2005). Recruitment and training policies and practices: The case of Turkey as an EU candidate. Journal of European Industrial Training, 29(9), 694-711.

Tharenou, P., Saks, A., \& Moore, C. (2007). A review and critique of research on training and organizational level outcomes. Human Resource Management Review, 17(3), 251-273.

Turner. C. (1933). Test room studies in employee effectiveness. American Journal of Public Health and the Nations Health, 23(6), 577-584.

Venkatraman, N. (1990). Performance implications of strategic coalignment: A methodological perspective. Journal of Management Studies, 27(1), 19-41.

Venkatraman, N., \& Ramanujam, V. (1986). The measurement of business performance in strategy research: A comparison of approaches. Academy of Management Review, 11(4), 801-814.

Wall, T.D., Michie, J., Patterson, M., Wood, S.J., Sheehan, M., Clegg, C.W., \& West, M.A. (2004). On the validity of subjective measures of company financial performance. Personnel Psychology, 57(1), 95-118.

Wall, T.D., \& Wood, S.J. (2005). The romance of human resource management and business performance and the case for big science. Human Relations, 58(4), 429-462.

Webster, E., \& Wood, G. (2005). Human resource management practice and institutional constraints. Employee Relations, 27(4), 369-385. 
Whitley, R. (2010). Changing competition in market economies, Morgan, G., Campbell, J., Crouch, C., Pedersen, O., \& Whitley, R. (Eds.), The Oxford handbook of comparative institutional analysis. Oxford: Oxford University Press.

Wood, G., Dibben, P., Stride, C., \& Webster, E. (2010). 'HRM in Mozambique: homogenization, path dependence or segmented business system? Journal of World Business, 46(1), 31-41.

Wood, G., \& Frynas, G. (2006). The institutional basis of economic failure: Anatomy of the segmented business system, Socio-Economic Review, 4(2): 239-277.

Wood, G., \& Lane, C. (2012). Institutions, change and diversity, Lane, C., \& Wood, G. (Eds.), Capitalist diversity and diversity within capitalism. London: Routledge.

Wood, S.J. (1999). Human resource management and performance, 1(4), 367-413.

Wright, P., \& Oldford, A. (1993). Telecommuting and employee effectiveness. International Journal of Career Management, 5(1), 4-9.

Wright, P.M., McMahon, G.C., \& McWilliams, A. (1994). Human resource and sustained competitive advantage: A resource based perspective. International Journal of Human Resource Management, 5(2), 295-320.

Wright, P.M., McCormick, B., Sherman, W.S., \& McMahan, G.C. (1999). The role of human resources practices in petro-chemical refinery performance. International Journal of Human Resource Management, 10, 551-571.

Wright, P.M., McMahan, G.C., Snell, S.A., \& Gerhart, B. (2001). Comparing line and HR executives' perceptions of HR effectiveness: Services, roles, and contributions. Human Resource Management, 40(2), 111-123. 


\section{High Performance Work Systems}

\section{Outcomes}

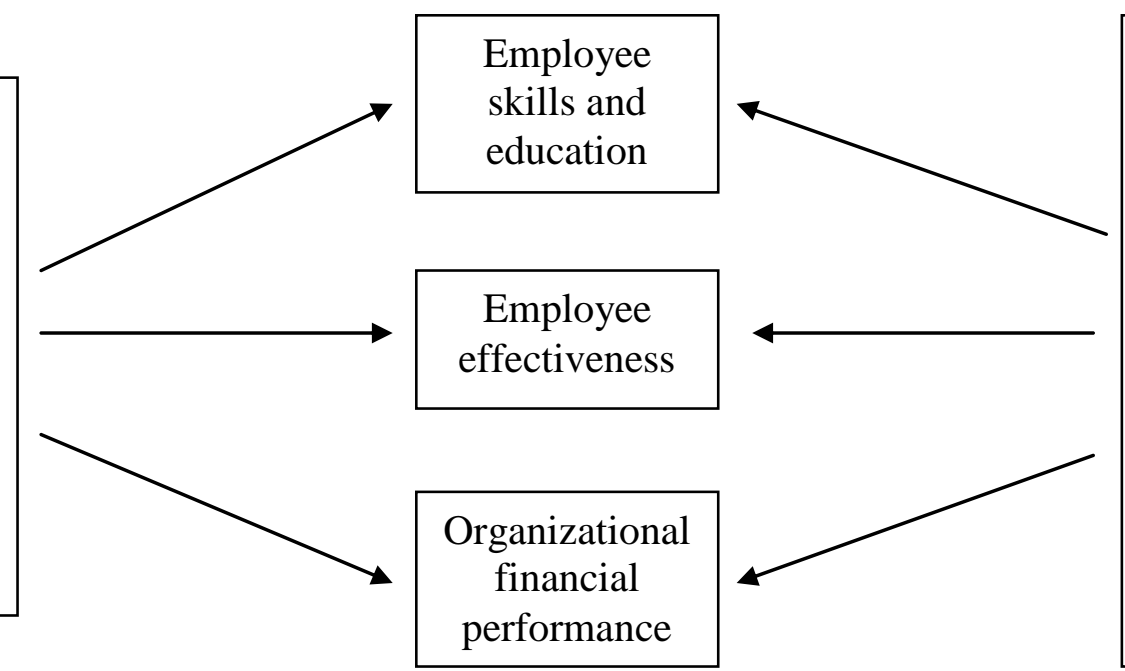

Control Variables

Subsidiary-level controls

- Firm age

- Firm size

- Organizational mode

- Establishment mode

Parent-level controls

- Parent size

- Parent diversity

- Nationality of MNE

Industry-level controls

Fig. 1: Conceptual framework 
Table 1: Characteristics of questionnaire respondent firms

\begin{tabular}{|c|c|c|c|}
\hline \multicolumn{2}{|l|}{ Characteristics } & Number & $\%$ \\
\hline \multirow{4}{*}{ Respondent type } & CEO (e.g. general manager, chairman) & 34 & 22.9 \\
\hline & Deputy general manager & 13 & 8.8 \\
\hline & HRM managers & 76 & 51.4 \\
\hline & Planning and other senior managers & 25 & 16.9 \\
\hline \multirow{2}{*}{ Organizational mode } & Wholly owned subsidiary & 88 & 59.5 \\
\hline & Joint venture & 60 & 40.5 \\
\hline \multirow{2}{*}{ Establishment mode } & Acquisition & 33 & 22.3 \\
\hline & Greenfield & 115 & 77.7 \\
\hline \multirow{9}{*}{ Country of origin } & USA & 44 & 29.6 \\
\hline & Germany & 33 & 22.3 \\
\hline & UK & 20 & 13.5 \\
\hline & France & 6 & 4.1 \\
\hline & Italy & 6 & 4.1 \\
\hline & Netherlands & 6 & 4.1 \\
\hline & Switzerland & 6 & 4.1 \\
\hline & Other EU countries & 10 & 6.7 \\
\hline & Asian countries & 17 & 11.5 \\
\hline \multirow{4}{*}{$\begin{array}{l}\text { Foreign parent } \\
\text { diversity }\end{array}$} & Single business & 29 & 19.6 \\
\hline & Dominant business & 59 & 39.8 \\
\hline & Related business & 45 & 30.4 \\
\hline & Unrelated business & 15 & 10.2 \\
\hline \multirow{10}{*}{ Industry sector } & Industrial, automotive and electrical equipment & 8 & 5.4 \\
\hline & Food, textile and paper & 9 & 6.1 \\
\hline & Metal, wood, leather and glass & 6 & 4.1 \\
\hline & Chemical and pharmaceuticals & 13 & 8.8 \\
\hline & Other manufacturing & 13 & 8.8 \\
\hline & Wholesale and retail trade & 18 & 12.2 \\
\hline & Computer and engineering services & 9 & 6.1 \\
\hline & Financial services and consultancy & 22 & 14.9 \\
\hline & Hospitality and leisure services & 24 & 16.2 \\
\hline & Other services & 26 & 17.6 \\
\hline \multirow{3}{*}{ Number of employees } & Small size & 23 & 15.5 \\
\hline & Medium size & 46 & 31.1 \\
\hline & Large size & 79 & 53.4 \\
\hline Years of operation & Mean & \multicolumn{2}{|c|}{19.22} \\
\hline & $N$ & \multicolumn{2}{|c|}{148} \\
\hline
\end{tabular}


Table 2: Descriptive statistics and correlation coefficients of variables

\begin{tabular}{|c|c|c|c|c|c|c|c|c|c|c|c|c|c|c|c|c|c|c|c|c|c|c|c|c|c|c|c|c|c|}
\hline Variable name & Mean & SD & 1 & 2 & 3 & 4 & 5 & 6 & 7 & 8 & 9 & 10 & 11 & 12 & 13 & 14 & 15 & 16 & 17 & 18 & 19 & 20 & 21 & 22 & 23 & 24 & 25 & 26 & 27 \\
\hline 1. PERF1 & 5.36 & 1.02 & 1.00 & & & & & & & & & & & & & & & & & & & & & & & & & & \\
\hline 2. PERF2 & 5.41 & 1.06 & 0.63 & 1.00 & & & & & & & & & & & & & & & & & & & & & & & & & \\
\hline 3. PERF3 & 5.36 & 1.79 & 0.33 & 0.28 & 1.00 & & & & & & & & & & & & & & & & & & & & & & & & \\
\hline 4. TRAINING (In) & 3.18 & 0.90 & 0.05 & 0.16 & 0.04 & 1.00 & & & & & & & & & & & & & & & & & & & & & & & \\
\hline 5. PERF_APP & 0.81 & 0.21 & 0.25 & 0.28 & 0.20 & -0.02 & 1.00 & & & & & & & & & & & & & & & & & & & & & & \\
\hline 6. PERF_COMP & 3.76 & 0.70 & 0.07 & 0.17 & 0.11 & 0.10 & 0.20 & 1.00 & & & & & & & & & & & & & & & & & & & & & \\
\hline 7. MERIT_PRO & 4.03 & 0.52 & 0.17 & 0.28 & 0.02 & 0.04 & 0.16 & 0.20 & 1.00 & & & & & & & & & & & & & & & & & & & & \\
\hline 8. INT_COMM & 4.02 & 0.63 & 0.30 & 0.41 & 0.16 & -0.01 & 0.07 & 0.18 & 0.33 & 1.00 & & & & & & & & & & & & & & & & & & & \\
\hline 9. EMPOWER & 3.85 & 0.66 & 0.22 & 0.36 & 0.09 & 0.00 & 0.05 & 0.23 & 0.43 & 0.46 & 1.00 & & & & & & & & & & & & & & & & & & \\
\hline 10. HRM_FIT & 4.03 & 0.84 & 0.22 & 0.28 & 0.13 & -0.05 & 0.35 & 0.24 & 0.28 & 0.31 & 0.45 & 1.00 & & & & & & & & & & & & & & & & & \\
\hline 11. AGE & 19.22 & 20.46 & 0.06 & 0.07 & 0.03 & -0.07 & 0.09 & 0.05 & 0.04 & 0.06 & 0.10 & 0.26 & 1.00 & & & & & & & & & & & & & & & & \\
\hline 12. LN_SIZE & 5.79 & 1.74 & 0.08 & -0.04 & 0.14 & -0.08 & 0.08 & 0.05 & 0.14 & -0.01 & 0.08 & 0.27 & 0.36 & 1.00 & & & & & & & & & & & & & & & \\
\hline 13. ORG_MODE & 0.41 & 0.49 & -0.06 & -0.19 & -0.05 & 0.11 & -0.03 & 0.07 & -0.07 & -0.33 & -0.07 & 0.01 & 0.12 & 0.09 & 1.00 & & & & & & & & & & & & & & \\
\hline 14. EST_MODE & 0.78 & 0.42 & -0.05 & 0.06 & 0.12 & 0.04 & 0.19 & 0.14 & -0.00 & 0.05 & -0.15 & 0.04 & 0.10 & -0.19 & 0.14 & 1.00 & & & & & & & & & & & & & \\
\hline 15. LN_FPSIZE & 8.44 & 2.85 & 0.06 & 0.01 & 0.03 & 0.10 & 0.18 & -0.03 & 0.11 & 0.09 & 0.14 & 0.32 & 0.16 & 0.50 & -0.12 & -0.12 & 1.00 & & & & & & & & & & & & \\
\hline 16. DIVER & 2.08 & 0.82 & 0.04 & 0.02 & 0.02 & -0.12 & 0.18 & -0.00 & 0.01 & 0.02 & 0.08 & 0.17 & 0.29 & 0.37 & -0.06 & -0.08 & 0.44 & 1.00 & & & & & & & & & & & \\
\hline 17. USA\&UK & 0.43 & 0.49 & 0.04 & 0.06 & -0.09 & 0.11 & -0.01 & 0.07 & 0.06 & 0.13 & 0.09 & 0.04 & -0.06 & -0.01 & -0.11 & -0.02 & 0.11 & 0.09 & 1.00 & & & & & & & & & & \\
\hline 18. EUROPE & 0.45 & 0.49 & 0.05 & 0.07 & 0.03 & -0.13 & -0.02 & -0.08 & -0.12 & -0.07 & 0.00 & 0.01 & 0.06 & 0.05 & 0.02 & -0.06 & -0.04 & -0.01 & -0.49 & 1.00 & & & & & & & & & \\
\hline 19. IND_ELECT & 0.05 & 0.22 & -0.08 & 0.01 & 0.07 & 0.05 & 0.05 & 0.07 & -0.03 & -0.08 & 0.08 & 0.06 & 0.17 & -0.06 & 0.17 & 0.13 & 0.00 & 0.01 & 0.03 & -0.09 & 1.00 & & & & & & & & \\
\hline 20. FOOD_TEXT & 0.06 & 0.24 & -0.09 & -0.04 & 0.06 & 0.03 & 0.04 & 0.07 & 0.06 & 0.04 & -0.03 & -0.09 & -0.12 & -0.09 & -0.09 & 0.07 & -0.07 & 0.01 & 0.23 & -0.17 & -0.06 & 1.00 & & & & & & & \\
\hline 21. METAL_WOOD & 0.04 & 0.19 & -0.04 & -0.08 & -0.22 & -0.09 & -0.01 & 0.02 & -0.06 & -0.02 & -0.07 & -0.02 & 0.03 & -0.05 & 0.10 & -0.05 & -0.08 & -0.14 & -0.11 & 0.09 & -0.05 & -0.05 & 1.00 & & & & & & \\
\hline 22. CHEM_PHAR & 0.09 & 0.28 & 0.16 & 0.10 & -0.07 & -0.01 & 0.15 & 0.09 & -0.03 & 0.11 & 0.12 & 0.06 & 0.11 & -0.01 & -0.11 & 0.11 & 0.16 & 0.17 & $\begin{array}{ll}-0.18 \\
\end{array}$ & 0.24 & -0.07 & -0.08 & -0.06 & 1.00 & & & & & \\
\hline 23. OTH_MANUF & 0.09 & 0.28 & 0.06 & 0.06 & 0.09 & -0.01 & -0.01 & -0.03 & -0.02 & 0.07 & 0.03 & -0.02 & -0.02 & -0.02 & -0.11 & -0.06 & -0.09 & 0.03 & 0.16 & -0.09 & -0.07 & -0.08 & -0.06 & -0.09 & 1.00 & & & & \\
\hline 24. TRADE & 0.12 & 0.32 & -0.09 & -0.21 & -0.12 & -0.10 & -0.13 & -0.08 & -0.09 & -0.19 & -0.19 & -0.05 & -0.12 & 0.02 & 0.07 & -0.05 & -0.06 & -0.06 & -0.03 & 0.12 & -0.09 & -0.09 & -0.08 & -0.11 & -0.11 & 1.00 & & & \\
\hline 25. COMP_ENG & 0.06 & 0.24 & 0.04 & 0.04 & -0.01 & 0.01 & -0.03 & -0.00 & -0.03 & 0.04 & 0.00 & -0.06 & -0.12 & -0.22 & 0.02 & 0.13 & -0.23 & -0.02 & 0.12 & -0.06 & -0.06 & -0.07 & -0.05 & -0.08 & -0.08 & -0.09 & 1.00 & & \\
\hline 26. FIN_CONS & 0.15 & 0.35 & -0.13 & -0.23 & 0.16 & -0.05 & $\begin{array}{l}-0.10 \\
\end{array}$ & -0.01 & 0.18 & $\begin{array}{l}-0.01 \\
\end{array}$ & 0.03 & -0.01 & 0.09 & 0.36 & 0.08 & -0.23 & 0.21 & 0.05 & $\begin{array}{l}-0.09 \\
\end{array}$ & -0.10 & $\begin{array}{l}-0.10 \\
\end{array}$ & -0.11 & -0.09 & -0.13 & -0.13 & -0.16 & $\begin{array}{l}-0.11 \\
\end{array}$ & 1.00 & \\
\hline 27. HOSP_LEIS & 0.16 & 0.37 & 0.10 & 0.23 & -0.06 & -0.01 & -0.03 & -0.19 & 0.01 & -0.00 & 0.02 & 0.02 & -0.07 & -0.16 & -0.10 & 0.01 & -0.08 & -0.20 & -0.01 & -0.11 & -0.11 & -0.11 & $\begin{array}{c}-0.09 \\
\end{array}$ & -0.14 & $\begin{array}{l}-0.14 \\
\end{array}$ & $\begin{array}{l}-0.16 \\
\end{array}$ & -0.11 & -0.18 & 1.00 \\
\hline
\end{tabular}

Notes:

Correlations of 0.22 or greater are significant at $p<0.01$.

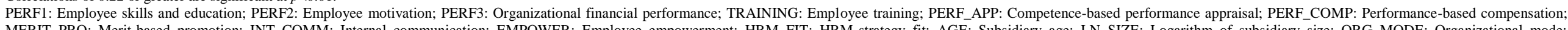

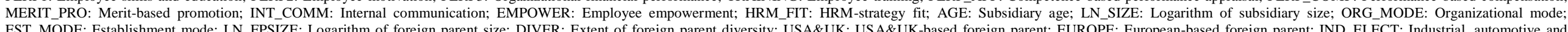

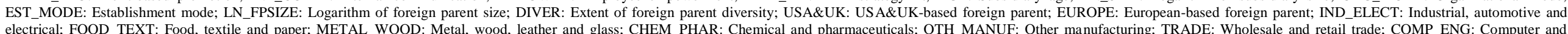
engineering services; FIN_CONS: Financial services and consultancy; HOSP_LEIS: Hospital and leisure services.

$N=148$ 
Table 3: Regression results (PERF1: Employee skills and education)

\begin{tabular}{|c|c|c|c|c|c|}
\hline Variable name & Definition & \multicolumn{2}{|c|}{ Model 1} & \multicolumn{2}{|c|}{ Model 2} \\
\hline \multicolumn{2}{|l|}{ Independent variables } & $\beta$ & Std. Error & $\beta$ & Std. Error \\
\hline TRAINING $\quad$ (H1a) & Employee training & & & 0.01 & 0.01 \\
\hline PERF_APP & Competence-based performance appraisal & & & $3.17 * *$ & 1.71 \\
\hline PERF_COMP & Performance-based compensation & & & 0.29 & 0.54 \\
\hline MERIT_PRO & Merit-based promotion & & & $0.59 *$ & 0.76 \\
\hline INT_COMM & Internal communication & & & $1.49 * * *$ & 0.64 \\
\hline EMPOWER & Employee empowerment & & & -0.33 & 0.70 \\
\hline HRM_FIT $\quad(\mathrm{H7a})$ & HRM-strategy fit & & & 0.01 & 0.04 \\
\hline \multicolumn{2}{|l|}{ Subsidiary-level controls } & & & & \\
\hline AGE & Subsidiary age & 0.01 & 0.02 & 0.01 & 0.01 \\
\hline LN_SIZE & Logarithm of subsidiary size & 0.07 & 0.23 & -0.09 & 0.24 \\
\hline ORG_MODE & Organizational mode & -0.13 & 0.68 & 0.51 & 0.75 \\
\hline EST_MODE & Establishment mode & -0.65 & 0.81 & -1.19 & 0.87 \\
\hline \multicolumn{2}{|l|}{ Parent-level controls } & & & & \\
\hline LN_FPSIZE & Logarithm of foreign parent size & 0.07 & 0.14 & 0.04 & 0.15 \\
\hline DIVER & Extent of foreign parent diversity & -0.23 & 0.45 & -0.15 & 0.48 \\
\hline USA\&UK & USA\&UK-based foreign parent & 0.18 & 1.17 & -0.05 & 1.26 \\
\hline EUROPE & European-based foreign parent & -0.16 & 1.16 & 0.17 & 1.24 \\
\hline \multicolumn{2}{|l|}{ Industry-level controls } & & & & \\
\hline IND_ELECT & Industrial, automotive and electrical equipment & -1.25 & 1.38 & -0.49 & 1.42 \\
\hline FOOD_TEXT & Food, textile and paper & -1.38 & 1.38 & -0.95 & 1.44 \\
\hline METAL_WOOD & Metal, wood, leather and glass & -0.77 & 1.76 & -0.47 & 1.81 \\
\hline CHEM_PHAR & Chemical and pharmaceuticals & 1.40 & 1.23 & 1.35 & 1.41 \\
\hline OTH_MANUF & Other manufacturing & -0.28 & 1.26 & 0.47 & 1.32 \\
\hline TRADE & Wholesale and retail trade & -2.07 & 1.28 & 1.08 & 1.52 \\
\hline COMP_ENG & Computer and engineering services & 0.73 & 1.63 & 1.56 & 1.80 \\
\hline FIN_CONS & Financial services and consultancy & $-2.19 * *$ & 1.13 & $-1.04 *$ & 1.22 \\
\hline HOSP_LEIS & Hospitality and leisure services & -0.16 & 1.17 & 0.70 & 1.31 \\
\hline \multicolumn{2}{|l|}{ Intercept } & \multicolumn{2}{|c|}{$16.39 * * *$} & \multicolumn{2}{|c|}{$5.96 * *$} \\
\hline \multicolumn{2}{|l|}{ F statistic } & \multicolumn{2}{|c|}{0.76} & \multicolumn{2}{|c|}{$1.97 * *$} \\
\hline \multicolumn{2}{|l|}{ R-square } & \multicolumn{2}{|c|}{0.12} & \multicolumn{2}{|c|}{0.24} \\
\hline \multicolumn{2}{|l|}{ Adjusted R-square } & \multicolumn{2}{|c|}{0.04} & \multicolumn{2}{|c|}{0.15} \\
\hline
\end{tabular}

\section{Notes:}

$* p<0.1 ; * * p<0.05 ; * * * p<0.01$

$N=148$ 
Table 4: Regression results (PERF2: Employee effectiveness)

\begin{tabular}{|c|c|c|c|c|c|}
\hline Variable name & Definition & \multicolumn{2}{|c|}{ Model 1} & \multicolumn{2}{|c|}{ Model 2} \\
\hline \multicolumn{2}{|l|}{ Independent variables } & $\beta$ & Std. Error & $\beta$ & Std. Error \\
\hline TRAINING $\quad(\mathrm{H} 1 \mathrm{~b})$ & Employee training & & & $0.02 *$ & 0.01 \\
\hline PERF_APP & Competence-based performance appraisal & & & $4.78 * *$ & 2.59 \\
\hline PERF_COMP & Performance-based compensation & & & $0.41 * *$ & 0.83 \\
\hline MERIT_PRO & Merit-based promotion & & & $1.96 * * *$ & 1.15 \\
\hline INT_COMM & Internal communication & & & $1.80 * *$ & 0.98 \\
\hline EMPOWER & Employee empowerment & & & $0.90 * *$ & 1.07 \\
\hline HRM_FIT $\quad(H 7 b)$ & HRM-strategy fit & & & 0.35 & 0.73 \\
\hline \multicolumn{2}{|l|}{ Subsidiary-level controls } & & & & \\
\hline AGE & Subsidiary age & 0.01 & 0.02 & 0.01 & 0.02 \\
\hline LN_SIZE & Logarithm of subsidiary size & -0.20 & 0.37 & -0.45 & 0.37 \\
\hline ORG_MODE & Organizational mode & -0.84 & 1.11 & -0.30 & 1.14 \\
\hline EST_MODE & Establishment mode & 0.33 & 1.31 & 0.55 & 1.32 \\
\hline \multicolumn{2}{|l|}{ Parent-level controls } & & & & \\
\hline LN_FPSIZE & Logarithm of foreign parent size & 0.10 & 0.23 & 0.10 & 0.22 \\
\hline DIVER & Extent of foreign parent diversity & -0.10 & 0.73 & -0.20 & 0.74 \\
\hline USA\&UK & USA\&UK-based foreign parent & 2.54 & 1.89 & 1.63 & 1.90 \\
\hline EUROPE & European-based foreign parent & 1.81 & 1.87 & 1.86 & 1.88 \\
\hline \multicolumn{2}{|l|}{ Industry-level controls } & & & & \\
\hline IND_ELECT & Industrial, automotive and electrical equipment & -1.23 & 2.23 & -0.37 & 2.15 \\
\hline FOOD_TEXT & Food, textile and paper & -3.13 & 2.32 & -2.07 & 2.25 \\
\hline METAL_WOOD & Metal, wood, leather and glass & -0.63 & 2.85 & -0.36 & 2.73 \\
\hline CHEM_PHAR & Chemical and pharmaceuticals & -0.10 & 1.99 & 0.41 & 2.13 \\
\hline OTH_MANUF & Other manufacturing & -1.32 & 2.03 & -0.34 & 2.00 \\
\hline TRADE & Wholesale and retail trade & $-6.31 * * *$ & 2.07 & $-1.65 * *$ & 2.29 \\
\hline COMP_ENG & Computer and engineering services & -2.58 & 2.64 & -1.51 & 2.72 \\
\hline FIN_CONS & Financial services and consultancy & $-4.41 * * *$ & 1.83 & $-2.84 *$ & 1.85 \\
\hline HOSP_LEIS & Hospitality and leisure services & 0.48 & 1.90 & 1.83 & 1.97 \\
\hline \multicolumn{2}{|l|}{ Intercept } & \multicolumn{2}{|c|}{$27.09^{* * *}$} & \multicolumn{2}{|c|}{2.36} \\
\hline \multicolumn{2}{|l|}{ F statistic } & \multicolumn{2}{|c|}{$1.62 *$} & \multicolumn{2}{|c|}{$2.48 * * *$} \\
\hline \multicolumn{2}{|l|}{ R-square } & \multicolumn{2}{|c|}{0.22} & \multicolumn{2}{|c|}{0.42} \\
\hline \multicolumn{2}{|l|}{ Adjusted R-square } & \multicolumn{2}{|c|}{0.09} & \multicolumn{2}{|c|}{0.25} \\
\hline
\end{tabular}

Notes:

$* p<0.1 ; * * p<0.05 ; * * * p<0.01$

$N=148$ 
Table 5: Regression results (PERF3: Organizational financial performance)

\begin{tabular}{|c|c|c|c|c|c|c|}
\hline \multicolumn{2}{|l|}{ Variable name } & \multirow[t]{2}{*}{ Definition } & \multicolumn{2}{|c|}{ Model 1} & \multicolumn{2}{|c|}{ Model 2} \\
\hline \multicolumn{2}{|c|}{ Independent variables } & & $\beta$ & Std. Error & $\beta$ & Std. Error \\
\hline TRAINING & $(\mathrm{H} 1 \mathrm{c})$ & Employee training & & & 0.02 & 0.01 \\
\hline PERF_APP & $(\mathrm{H} 2 \mathrm{c})$ & Competence-based performance appraisal & & & $6.48 * * *$ & 3.05 \\
\hline PERF_COMP & $(\mathrm{H} 3 \mathrm{c})$ & Performance-based compensation & & & $0.89 *$ & 0.97 \\
\hline MERIT_PRO & $(\mathrm{H} 4 \mathrm{c})$ & Merit-based promotion & & & 0.81 & 1.39 \\
\hline INT_COMM & $(\mathrm{H} 5 \mathrm{c})$ & Internal communication & & & 1.04 & 1.20 \\
\hline EMPOWER & $(\mathrm{H6c})$ & Employee empowerment & & & 0.75 & 1.25 \\
\hline HRM_FIT & $(\mathrm{H} 7 \mathrm{c})$ & HRM-strategy fit & & & 0.35 & 0.87 \\
\hline \multicolumn{3}{|c|}{ Subsidiary-level controls } & & & & \\
\hline AGE & & Subsidiary age & -0.03 & 0.03 & -0.05 & 0.03 \\
\hline LN_SIZE & & Logarithm of subsidiary size & $0.74 * *$ & 0.43 & 0.50 & 0.46 \\
\hline ORG_MODE & & Organizational mode & -0.86 & 1.24 & -0.59 & 1.44 \\
\hline EST_MODE & & Establishment mode & $2.63 * *$ & 1.44 & $2.33^{*}$ & 1.51 \\
\hline \multicolumn{3}{|c|}{ Parent-level controls } & & & & \\
\hline LN_FPSIZE & & Logarithm of foreign parent size & 0.05 & 0.27 & -0.15 & 0.28 \\
\hline DIVER & & Extent of foreign parent diversity & -0.84 & 0.82 & -0.45 & 0.89 \\
\hline USA\&UK & & USA\&UK-based foreign parent & -1.80 & 2.04 & -2.25 & 2.23 \\
\hline EUROPE & & European-based foreign parent & 1.39 & 1.98 & 1.74 & 2.13 \\
\hline \multicolumn{3}{|c|}{ Industry-level controls } & & & & \\
\hline IND_ELECT & & Industrial, automotive and electrical equipment & 2.14 & 2.44 & 2.68 & 2.48 \\
\hline FOOD_TEXT & & Food, textile and paper & 2.55 & 2.67 & 3.04 & 2.78 \\
\hline METAL_WOOD & & Metal, wood, leather and glass & $-5.48 * *$ & 2.98 & $-5.25 * *$ & 3.02 \\
\hline CHEM_PHAR & & Chemical and pharmaceuticals & -3.25 & 2.46 & $-5.85 * *$ & 2.90 \\
\hline OTH_MANUF & & Other manufacturing & $3.90 *$ & 2.33 & $5.00 * *$ & 2.42 \\
\hline TRADE & & Wholesale and retail trade & -2.13 & 2.19 & 1.26 & 2.58 \\
\hline COMP_ENG & & Computer and engineering services & 0.24 & 2.79 & 0.36 & 3.07 \\
\hline FIN_CONS & & Financial services and consultancy & 1.08 & 1.94 & $3.71 *$ & 2.10 \\
\hline HOSP_LEIS & & Hospitality and leisure services & -2.52 & 2.14 & -1.48 & 2.43 \\
\hline \multicolumn{3}{|l|}{ Intercept } & \multicolumn{2}{|c|}{$12.37 * * *$} & \multicolumn{2}{|c|}{-0.28} \\
\hline \multicolumn{3}{|l|}{ F statistic } & \multicolumn{2}{|c|}{1.37} & \multicolumn{2}{|c|}{$1.98 * *$} \\
\hline \multicolumn{3}{|l|}{ R-square } & \multicolumn{2}{|c|}{0.22} & \multicolumn{2}{|c|}{0.33} \\
\hline \multicolumn{3}{|l|}{ Adjusted R-square } & \multicolumn{2}{|c|}{0.07} & \multicolumn{2}{|c|}{0.16} \\
\hline
\end{tabular}

Notes:

$* p<0.1 ; * * p<0.05 ; * * * p<0.01$

$N=148$ 
Appendix: Measurement of constructs

\begin{tabular}{|c|c|c|}
\hline Construct/Cronbach alpha & Items & Source \\
\hline $\begin{array}{l}\text { Employee skills and education } \\
\text { (PERF1; } \alpha=0.85)\end{array}$ & $\begin{array}{l}\text { Relative to the employees of your major competitors in your industry, how would you rate the quality of your } \\
\text { subsidiary's employees on each of the following dimensions? (7-point scales, where } 1=\text { far below average and } 7=\text { far } \\
\text { above average) } \\
\text { 1. Overall ability } \\
\text { 2. Job related skills } \\
\text { 3. Educational level }\end{array}$ & $\begin{array}{l}\text { Fey et al. (2009); } \\
\text { Collings et al. (2010) }\end{array}$ \\
\hline $\begin{array}{l}\text { Employee effectiveness (PERF2; } \\
\alpha=0.92)\end{array}$ & $\begin{array}{l}\text { Relative to the employees of your major competitors in your industry, how would you rate the quality of your } \\
\text { subsidiary's employees on each of the following dimensions? (7-point scales, where } 1=\text { far below average and } 7=\text { far } \\
\text { above average) } \\
\text { 1. Motivation } \\
\text { 2. Organizational commitment } \\
\text { 3. Job satisfaction } \\
\text { 4. Flexibility/adaptability } \\
\text { 5. Work effort }\end{array}$ & Collings et al. (2010) \\
\hline $\begin{array}{l}\text { Organizational financial } \\
\text { performance (PERF3; } \alpha=0.88)\end{array}$ & $\begin{array}{l}\text { Over the last } 3 \text { years, please indicate your subsidiary's performance relative to its competitors in the following areas } \\
\text { (7-point scales, where } 1=\text { definitely worse and } 7=\text { definitely better): } \\
\text { 1. Profit margin growth } \\
\text { 2. Sales growth } \\
\text { 3. Profit margin }\end{array}$ & $\begin{array}{l}\text { Kaya (2006); } \\
\text { Collings et al. (2010) }\end{array}$ \\
\hline $\begin{array}{l}\text { Employee training (TRAINING; } \\
\alpha=0.85)\end{array}$ & $\begin{array}{l}\text { 1. Number of days of formal training managerial employees receives annually. } \\
\text { 2. Number of days of formal training non-managerial employees receives annually. }\end{array}$ & $\begin{array}{l}\text { Minbaeva et al. (2003); } \\
\text { Björkman et al. (2007); } \\
\text { Fey et al. (2009) }\end{array}$ \\
\hline $\begin{array}{l}\text { Competence-based performance } \\
\text { appraisal (PERF_APP; } \alpha=0.68 \text { ) }\end{array}$ & $\begin{array}{l}\text { 1. Proportion of jobs where a formal job analysis has been conducted (in per cent). } \\
\text { 2. Proportion of the employees that regularly receive a formal evaluation of their performance (in per cent). } \\
\text { 3. Proportion of new jobs for which a formal analysis of the desired personal (in per cent) } \\
\text { skills/competencies/characteristics is carried out prior to making a selection decision (in per cent). }\end{array}$ & $\begin{array}{l}\text { Minbaeva et al. (2003); } \\
\text { Fey et al. (2009) }\end{array}$ \\
\hline $\begin{array}{l}\text { Performance-based compensation } \\
\text { (PERF_COMP; } \alpha=0.64)\end{array}$ & $\begin{array}{l}\text { Please provide answers to the following questions (5-point scales, where } 1=\text { not at all and } 5=\text { to a large extent): } \\
\text { 1. The extent to which subsidiary uses performance-based compensation. } \\
\text { 2. The extent to which compensation system is closely connected with the financial results of the subsidiary. } \\
\text { 3. The extent to which pay is tied to individual performance. } \\
\text { 4. The extent to which differences in pay across employees in the subsidiary represent differences in their } \\
\text { contribution to the subsidiary. }\end{array}$ & $\begin{array}{l}\text { Wright et al. (1999); } \\
\text { Minbaeva et al. (2003); } \\
\text { Björkman et al. (2007); } \\
\text { Fey et al. (2009) }\end{array}$ \\
\hline $\begin{array}{l}\text { Merit-based promotion } \\
\text { (MERIT_PRO; } \alpha=0.63 \text { ) }\end{array}$ & $\begin{array}{l}\text { Please provide answers to the following questions ( } 5 \text {-point scales, where } 1=\text { not at all and } 5=\text { to a large extent): } \\
\text { 1. The extent to which upper-level vacancies are filled from within. } \\
\text { 2. The extent to which qualified employees have the opportunity to be promoted to positions of greater pay and/or } \\
\text { responsibility within the company. } \\
\text { 3. The extent to which the subsidiary places a great deal of importance on merit when making promotion decisions. }\end{array}$ & $\begin{array}{l}\text { Fey et al. (2000); } \\
\text { Minbaeva et al. (2003); } \\
\text { Björkman et al. (2007); } \\
\text { Fey et al. (2009) }\end{array}$ \\
\hline
\end{tabular}


Appendix: (Continued)

\begin{tabular}{|c|c|c|}
\hline Construct & Items & Source \\
\hline $\begin{array}{l}\text { Internal communication } \\
\text { (INT_COMM ; } \alpha=0.75 \text { ) }\end{array}$ & $\begin{array}{l}\text { Please provide answers to the following questions (5-point scales, where } 1=\text { not at all and } 5=\text { to a large extent): } \\
\text { 1. The extent to which communication flows well between employees in different departments. } \\
\text { 2. The extent to which communication flows well between non-managerial employees and managerial employees. } \\
\text { 3. The extent to which communication between the HRM department and the top management team is effective. }\end{array}$ & $\begin{array}{l}\text { Minbaeva et al. 2003); } \\
\text { Björkman et al. (2007); } \\
\text { Fey et al. (2009) }\end{array}$ \\
\hline $\begin{array}{l}\text { Employee empowerment } \\
(\text { EMPOWER; } \alpha=0.71)\end{array}$ & $\begin{array}{l}\text { Please provide answers to the following questions (5-point scales, where } 1=\text { not at all and } 5=\text { to a large extent): } \\
\text { 1. The extent to which employee input and suggestions are highly encouraged. } \\
\text { 2. The extent to which employee input and suggestions are often implemented. } \\
\text { 3. The extent to which employees' capabilities are viewed as the subsidiary's main source of competitive } \\
\text { advantage. }\end{array}$ & Collings et al. (2010) \\
\hline $\begin{array}{l}\text { HRM-strategy fit (HRM_FIT; } \\
\alpha=0.85)\end{array}$ & $\begin{array}{l}\text { Please provide answers to the following questions (5-point scales, where } 1=\text { not at all and } 5=\text { to a large extent): } \\
\text { 1. The extent to which the subsidiary makes an explicit effort to align business and HRM strategies. } \\
\text { 2. The extent to which the HRM department is involved in the strategic planning process. } \\
\text { 3. The extent to which HRM managers are viewed by those outside the function as partners in the management of } \\
\text { the business and agents for change. }\end{array}$ & $\begin{array}{l}\text { Fey et al. (2000); } \\
\text { Fey and Björkman (2001); } \\
\text { Björkman et al. (2007); } \\
\text { Collings et al. (2010) }\end{array}$ \\
\hline
\end{tabular}

